University of Rhode Island

DigitalCommons@URI

Open Access Master's Theses

1983

\title{
LAND VALUES AND DEVELOPMENT PATTERNS IN AN URBAN FRINGE COMMUNITY : EAST GREENWICH, RHODE ISLAND
}

Sarah Elizabeth Hughes

University of Rhode Island

Follow this and additional works at: https://digitalcommons.uri.edu/theses

\section{Recommended Citation}

Hughes, Sarah Elizabeth, "LAND VALUES AND DEVELOPMENT PATTERNS IN AN URBAN FRINGE

COMMUNITY : EAST GREENWICH, RHODE ISLAND" (1983). Open Access Master's Theses. Paper 582.

https://digitalcommons.uri.edu/theses/582

This Thesis is brought to you for free and open access by DigitalCommons@URI. It has been accepted for inclusion in Open Access Master's Theses by an authorized administrator of DigitalCommons@URI. For more information, please contact digitalcommons-group@uri.edu. 


\title{
LAND VALUES AND DEVELOPMENT PATTERNS IN AN URBAN FRINGE COMMUNITY: EAST GREENWICH, RHODE ISLAND
}

\author{
BY \\ SARAH ELIZABETH HUGHES \\ A RESEARCH PROJECT SUBMitTED IN \\ PARTIAL FULFILLMENT OF THE REQUIREMENTS \\ FOR THE DEGREE OF MASTER OF \\ COMMUNITY PLANNING
} UNIVERSITY OF RHODE ISLAND 1983 
Short title to be used on spine of binding, if full

title, as given on title page, is not acceptable:

\section{LAND VALUES IN AN URBAN FRINGE COMMUNITY}

(For Master's Research Project of Sarah E. Hughes) 


\section{MASTER OF COMMUNITY PLANNING}

RESEARCH PROJECT

OF

SARAH ELIZABETH HUGHES

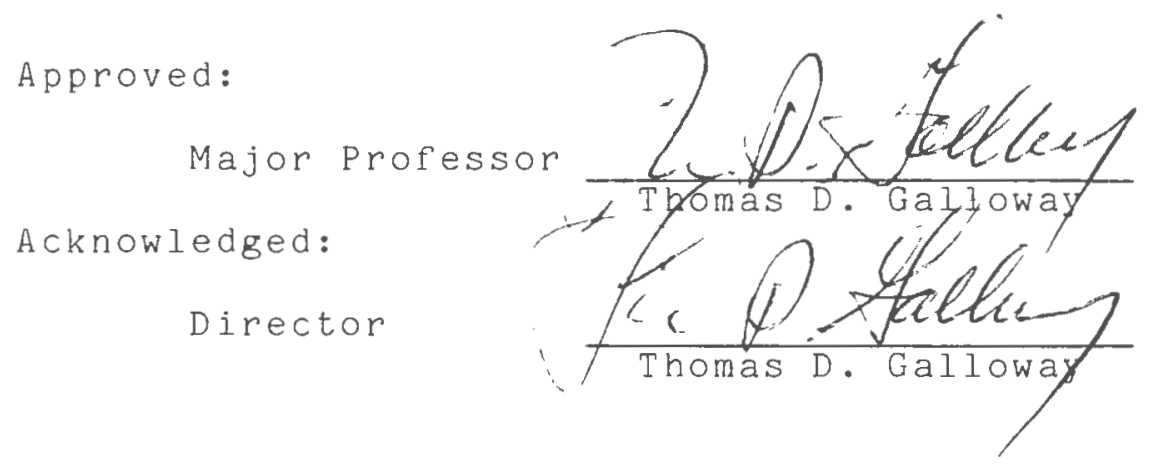




\section{ACKNOWLEDGEMENTS}

The preparation of this study would have been impossible without the assistance and cooperation of many individuals. I would like to recognize, in particular, the officials and staff of the Town of East Greenwich who never tired of answering my endless questions and made available all of the Town records necessary to complete this work. Special thanks go to my advisor in this venture, Dr. Thomas D. Galloway of the Graduate Curriculum in Community Planning and Area Development, for his guidance and support; to Dr. John J. Kupa of the Graduate Curriculum in Community Planning and Area Development and Mr. John C. Simmons, Town Manager of East Greenwich, for their assistance as readers; to Michael Embury, Town Planner of East Greenwich, for being a flexible employer while I worked on this project; and to Henry V. Boezi, Assistant Town Engineer, for his infinite patience with my interruptions. 


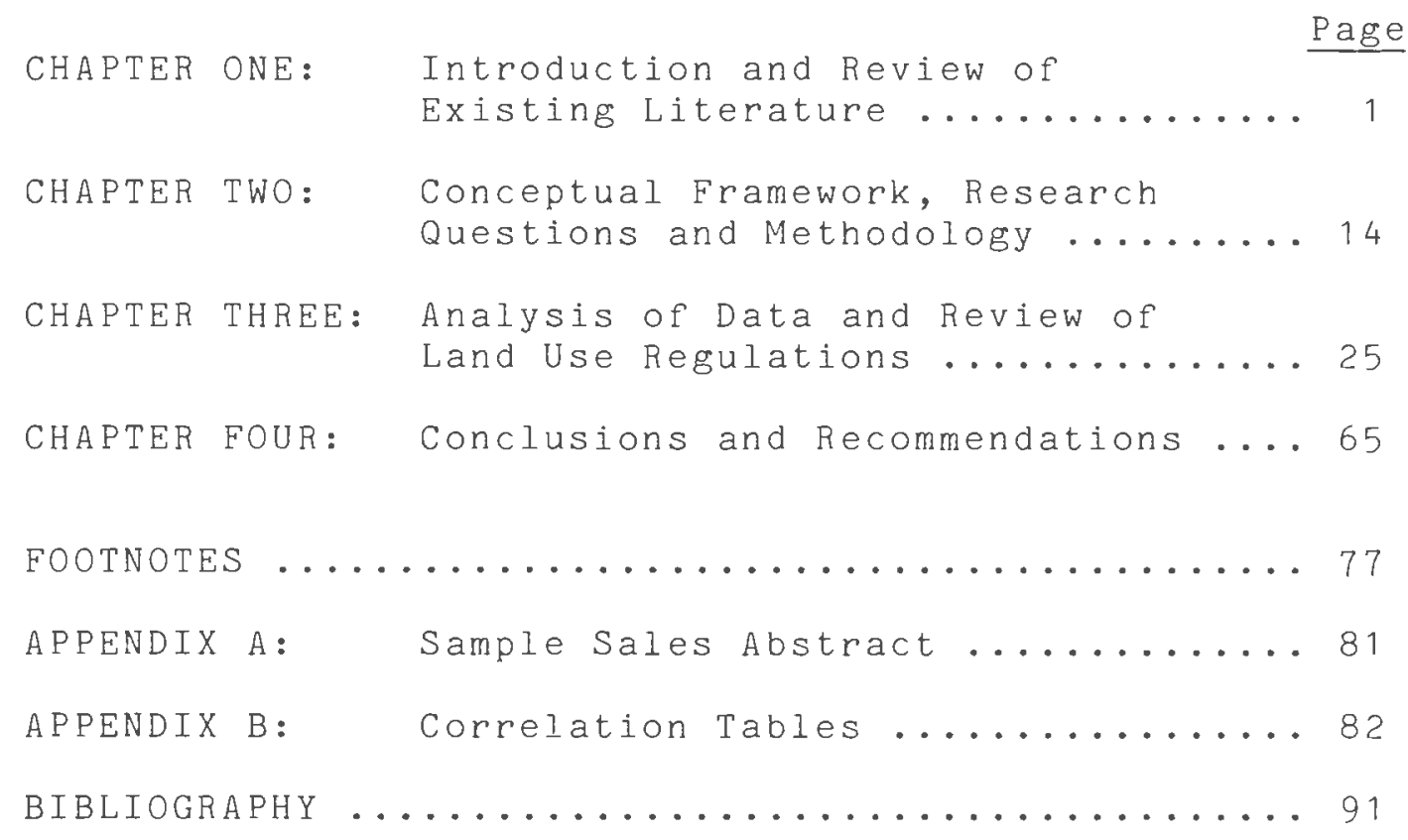


LIST OF TABLES

\begin{tabular}{|c|c|}
\hline ble & Title \\
\hline 1 . & $\begin{array}{l}\text { Population and Housing, East } \\
\text { Greenwich: } 1920-1980 \ldots \ldots \ldots \ldots \ldots\end{array}$ \\
\hline 2 . & $\begin{array}{l}\text { Population and Housing Change, } \\
\text { East Greenwich: } 1920-1980 \ldots \ldots \ldots \ldots\end{array}$ \\
\hline 3 . & $\begin{array}{l}\text { Building Permits Issued for Privately } \\
\text { Owned Housing Units: } 1950-1982 \ldots \ldots 28\end{array}$ \\
\hline 4. & Locations of Land Sales: $1963-1982 \ldots \ldots 35$ \\
\hline 5 . & $\begin{array}{l}\text { Average Per Acre Price of Vacant } \\
\text { Land: } 1963-1982 \ldots \ldots \ldots \ldots \ldots \ldots \ldots \ldots \ldots \ldots\end{array}$ \\
\hline 6 . & $\begin{array}{l}\text { Average Per Acre Price of Vacant } \\
\text { Land, By Area: } 1963-1982 \ldots \ldots \ldots \ldots \ldots\end{array}$ \\
\hline 7 . & $\begin{array}{l}\text { Average Per Acre Price of Vacant } \\
\text { Land, By Lot Size: 1963-1982 ........4 } 41\end{array}$ \\
\hline 8 . & $\begin{array}{l}\text { Average Per Acre Price of Vacant } \\
\text { Land, By Public water Availability: } \\
1963-1972 \text { and 1973-1982 .......... } 44\end{array}$ \\
\hline 9 . & $\begin{array}{l}\text { Average Per Acre Price of Vacant } \\
\text { Land, By Public Sewer Availability: } \\
1963-1972 \text { and 1973-1982 . . . . . } 44\end{array}$ \\
\hline 10. & $\begin{array}{l}\text { Average Per Acre Price of Vacant } \\
\text { Land, By Proportion of Land Area in } \\
\text { wetlands: 1963-1972 and 1973-1982 .....4 } 47\end{array}$ \\
\hline 11. & $\begin{array}{l}\text { Average Per Acre Price of Vacant } \\
\text { Land, By Proportion of Land with } \\
\text { Severe Soil Limitations: } 1963-1972 \\
\text { and } 1973-1982 \ldots \ldots \ldots \ldots \ldots \ldots \ldots \ldots \ldots \ldots \ldots\end{array}$ \\
\hline 12. & $\begin{array}{l}\text { Average Price Differentials Between } \\
\text { Easy to Develop and Hard to Develop } \\
\text { Land, By Physical Characteristic: } \\
1963-1972 \text { and } 1973-1982 \ldots \ldots \ldots . \ldots . \ldots 48\end{array}$ \\
\hline 13. & $\begin{array}{l}\text { Variables Used in Correlation } \\
\text { Equation } \ldots \ldots \ldots \ldots \ldots \ldots \ldots \ldots \ldots \ldots \ldots\end{array}$ \\
\hline
\end{tabular}


Variables With Greatest Correlation

to Per Acre Price: 1963-1982 .........55

15. Variables With Greatest Correlation to Per Acre Price, By Time Period: $1963-1972$ and $1973-1982 \ldots \ldots \ldots \ldots \ldots$

16. Number of Developed Parcels, By Public Facility Accessibility:

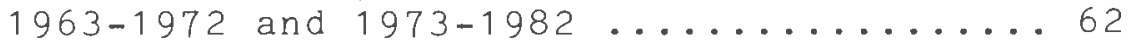

17. Number of Developed Parcels, By Presence of Environmental Development Limitations: 1963-1972 and 1973-1982 ....63 


\section{LIST OF FIGURES}

\begin{tabular}{|c|c|c|c|}
\hline Figure & Title & & Page \\
\hline 1 . & Rhode Island Cities and Towns & $\ldots \ldots \ldots$ & 15 \\
\hline 2 . & $\begin{array}{l}\text { East Greenwich: Neighborhood } \\
\text { Classification } \ldots \ldots \ldots \ldots \ldots\end{array}$ & $\ldots \ldots \ldots \ldots$ & 17 \\
\hline 3 . & $\begin{array}{l}\text { Public Water Service Areas in } \\
\text { East Greenwich: } 1963 \text { and } 1983\end{array}$ & $\ldots \ldots \ldots$ & 32 \\
\hline 4. & $\begin{array}{l}\text { Public Sewer Service Areas in } \\
\text { East Greenwich: } 1963 \text { and } 1973\end{array}$ & & 33 \\
\hline 5 . & Location of Land Sales: 1963-1 & $982 \ldots \ldots$ & 36 \\
\hline
\end{tabular}




\section{CHAPTER ONE}

Small towns on the urban fringe have experienced many changes over the past fifty years. With advancing technology, their effective distance from the urban center has been shortened. Improved transportation and communication systems have made the city much more accessible. People can now work in the city, yet live in the country. This reduces the strength of the local economic base, but increases residentially oriented activity.

The exodus to the country resulted in widespread land speculation and hundreds of new suburban communities. Large tracts of land, previously vacant or sometimes farmed, at the fringes of urban areas were subdivided and sold for house lots to provide space for the growing urban population. Rising land values led to rampant speculation and the result was often unplanned scattered subdivisions that "leap-frogged" across the land.

This inefficient use of the land led to problems with municipal facilities and service delivery. The costs fell heavily upon local governments. This led to the adoption of various land use controls, including zoning and subdivision regulations. Most of these land use controls are adopted and implemented on the local level. Over time, the traditional zoning and subdivision regulations have been supplemented by more innovative approaches. While these new techniques 


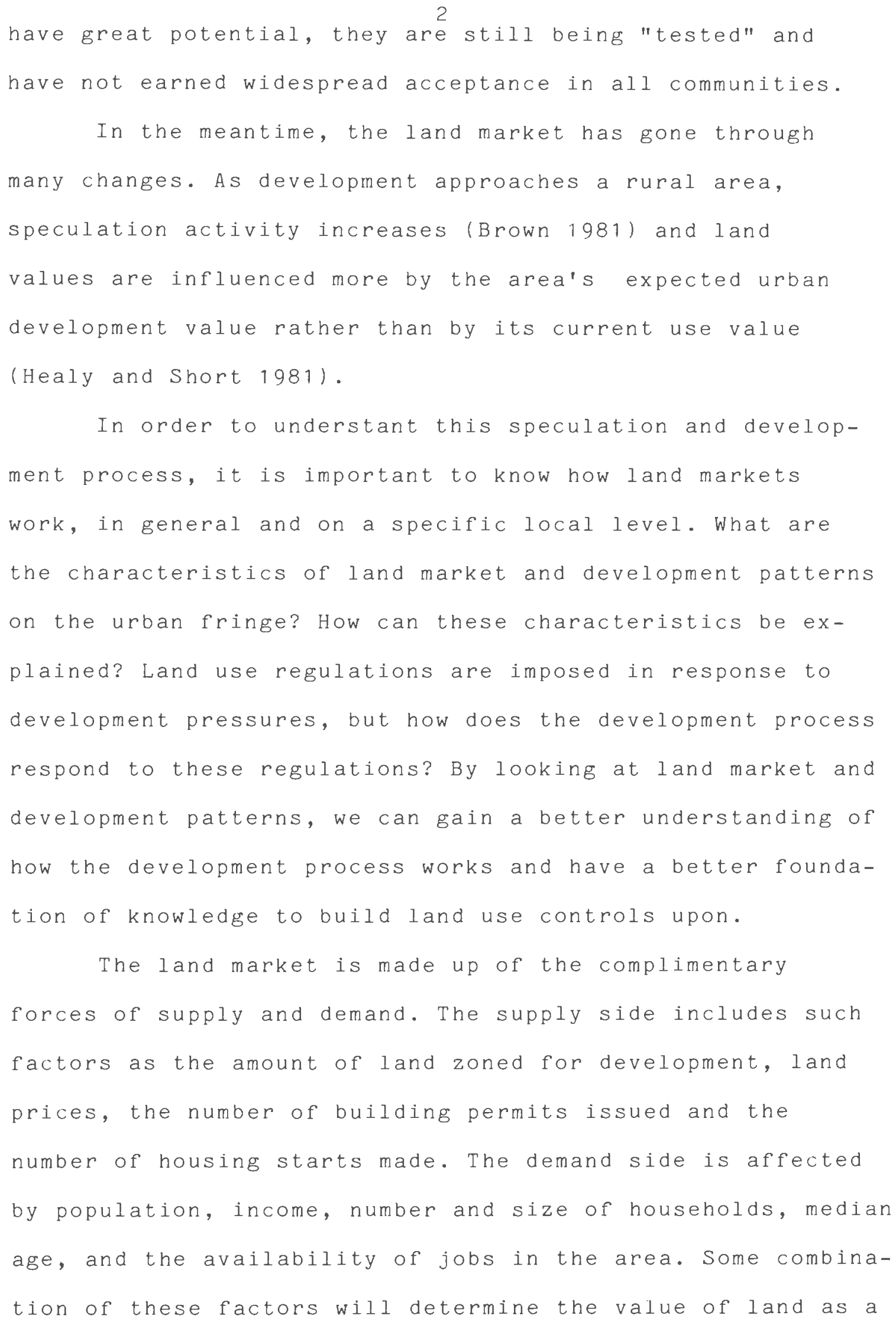


3

commodity and how much a person will pay for it.

Physical and locational characteristics will also

play a part in the purchase decision of a knowledgable

land market participant. Increasing regulation of the development of wetlands, farmlands, drinking water watersheds, and stricter controls for water supply and waste disposal

have made these factors important in land market operations.

Home builders are emphasizing locational advantages of

their properties such as the proximity of schools, shopping and highway intersections.

Just how important are these factors, and how has

their role changed over time? What is the relationship

between land market activities and land use controls?

This study will follow the market patterns for vacant

land in one community on the fringe of a metropolitan area.

The town selected for this study is East Greenwich, Rhode

Island which is located fifteeen miles from the city of

Providence. During the past twenty years, East Greenwich

has experience substantial development of what was pre-

viously vacant or farmed land. The purpose of the study is

to generate a better understanding of what factors influ-

ence land markets in the Town of East Greenwich.

While this study looks at only one town in a metro-

politan area, it is hoped that some of the findings can be

generalized to contribute to a better understanding of land

markets on the Providence urban fringe.

Suburban and rural towns across the country have been 
faced with increasing development pressures over the past two or three decades as a result of the dramatic population shift from urban centers toward these less populated areas. This has been followed more recently by a revival of interest in rural planning issues, highlighted by the search for an understanding of the operation of rural land markets.

In the past forty years, the rural landscape has been significantly altered. The number of farms in this country has dropped from 6.1 million to 2.3 million (Healy and Short 1981), and tens of millions of acres have been transformed from active agriculture and other traditional rural uses to subdivisions and other non-traditional uses. In Rhode Island, between 1950 and 1974, eighty-three thousand acres were removed from farm use, an area almost eight times the size of East Greenwich (U.S. Census of Agriculture 1974). East Greenwich itself was losing farmland at an average rate of twenty-eight acres a year (R.I. Department of Community Affairs 1981). Ownership has passed from farmers to speculators and investors. Public interest in outdoor recreation has led to intense demand for aesthetically pleasing rural properties, while the middle class American's search for privacy has removed thousands of acres from active production to passive "personal privacy buffers." One result of these changes has been large scale speculation in land, with consequent high costs to the actual settler. This leads to large areas being priced out of any potential market, except that of urban use, often 
the individual community and strict enforcement, but notes that such controls tend to increase the price of developable land by reducing the available supply.

A recent study of landowners in West Greenwich, Rhode Island (Cronin 1981) found that current zoning and land use controls were not likely to influence development, perhaps because of the delay in their implementation until after preliminary phases of land speculation and development have begun. Long term market forces were seen as most influential. Landowners were concerned about property taxes, but did not see them as a reason to sell their land. On the other hand, they did see pressure from neighboring parcels developed for more intensive uses and higher land prices as potential factors in encouraging them to sell in the future. Before attempting to determine the role played by land use controls, it is necessary to understand where they began and how they arrived at their present status. The orderly use and development of land is the focus of land use planning. Virtually all states have enacted land use laws which enable cities and towns to have some control over the land development process within their jurisdictions. Land use planning is the process in which various types of controls are used to shape future land development and to preserve existing land development without chaotic change (Hagman 1971). The traditional legal tools that are used by cities and towns to shape development include the application of the municipality's police power in the form of zoning 
10

and subdivision regulations. Other means include building codes, performance standards, land covenants, taxation, transfer of development rights and even development moratoria.

In reviewing land use planning and regulation in its present form, it is important to understand how it arrived at its present status. While land use planning today generally has its foundations in the Standard Planning Enabling Act of 1928 (SCEA), the Standard Zoning Enabling Act of 1922 (SZEA), the national Housing Act of 1949 and the Section 701 Program of the national Housing Act of 1954 , various types of land use controls have been in existence since the beginning of urban development. The SCEA and the SZEA form the models around which state planning, zoning and subdivision enabling legislation evolved. This state level legislation allowed municipalities to create planning boards and commissions which had responsibility for preparing comprehensive plans, developing zoning and subdivision regulations to support that plan, and reviewing development applications for their conformance to zoning and subdivision regulations and their conformance with the plan.2 Title I, Section 7 of the SCEA states that: "The plan shall be made with the general purpose of guiding and accomplishing a coordinated, adjusted and harmonious development of the municipality and its environs..." (U.S. Department of Commerce 1928). The housing boom that followed the second World war 
forced a further refinement of the land use regulation process to provide for adequate public facilities such as streets, water, sewers, parks and open space. Additional refinements are taking place in the 1980's as communities become more concerned about sprawl, loss of farmland, and generally inefficient use of the land.

Fiscal and environmental impacts of development are now being considered in reviewing development proposals as communities become more and more aware of the long term costs involved in supporting urban land uses and the impact they have on air and water quality, soil stability and wildlife habitat (Mahayni and Reich 1979).

The Rhode Island General Assembly enacted zoning enabling legislation in 1929 (G.L.R.I. 45-23-Zoning Ordinances, formerly P.L. 1921, Chapter 3069), one of the first states to do so, but it was more than twenty years before municipalities were given the power to adopt subdivision regulations (G.L.R.I. 45-23-Local Planning Boards and Commissions).

Over the years since the enabling legislation was passed, every city and town in Rhode IsLand has adopted a zoning ordinance and subdivision regulations. Many of these have been subsequently amended and updated in response to changing needs, issues, new theories and ideas. Each city or town now has its own set of regulations that specifically address the guidelines of the comprehensive plan. A few towns have gone beyond the traditional ordinances to include 
sections for Planned Unit Developments (PUD's), Planned

Multi-family Developments (PMFD's) and Cluster Developments.

While the State of Rhode Island was one of the first

to adopt zoning enabling legislation, thereby allowing its

towns and cities to have more control over land development, it did so before adopting legislation providing that zoning must be in conformance with a comprehensive or master plan (G.L.R.I. $1956 \S 45-24-4.1$ ). This weakens the power of zoning regulations considerably. A recent Rhode Island Supreme Court case, Sweetman v. Town of Cumberland 1976 , found that a zoning action could not be determined invalid for failure to comply with the master plan because:

[The] statute permitting a municipality to establish and amend zoning ordinances and requiring that all such acts follow a comprehensive plan does not mandate that zoning ordinances conform with [the] master plan adopted by the planning board. G.L.R.I. 1956\$ 45-24-3 (Sweetman v. Town of Cumberland, 364 A.2nd 1277).

While this finding has not been widely tested since it was made, its potential impact on the foundations of land use controls cannot be ignored. It is bound to come up again unless remedial action is taken in the near future. ${ }^{3}$

This chapter has included a discussion of some of the issues involved in the rural land market, and a review of related research in the field of rural land development. It also covered the factors which affect the rural land market and the legal foundations of the land use regulations used to control this development. The next chapter will 
13

further define the conceptual framework and methodology of this study and relate the discussion in this chapter to the specific sample community selected. Chapter Three contains the results and analysis of the data and a review of the history of land use regulation in East Greenwich. The final chapter provides conclusions regarding land devilopment in East Greenwich and the effect of land use regulartions on that development, and recommendations for future land use regulations and their implementation. 
In order to study the land development and regulation process, it was necessary to select a community that has experienced significant subdivision activity, yet still had large areas of undeveloped land which could potentially gain or lose from the implementation of land use regulations. The reasoning behind this is that while urbanized communities have had their physical character determined for them by the type of growth and development they have already experienced, rural towns have not. The character of future land use regulations will influence the character of future development and the entire community. Therefor, towns with large areas of undeveloped land have the most to gain from a better understanding of the development process and the implementation of land use regulations. The community selected as the study area for this investigation, East Greenwich, Rhode Island, was chosen because of its well established suburban reputation and the level of subdivision activity it has experienced through the past three decades.

East Greenwich is located in the center of the state of Rhode Island, on the western shore of Narragansett Bay, and about fifteen miles south of the city of Providence. See Figure 1. It is on the dividing line between the rural towns to the south and the more urban communities to the 


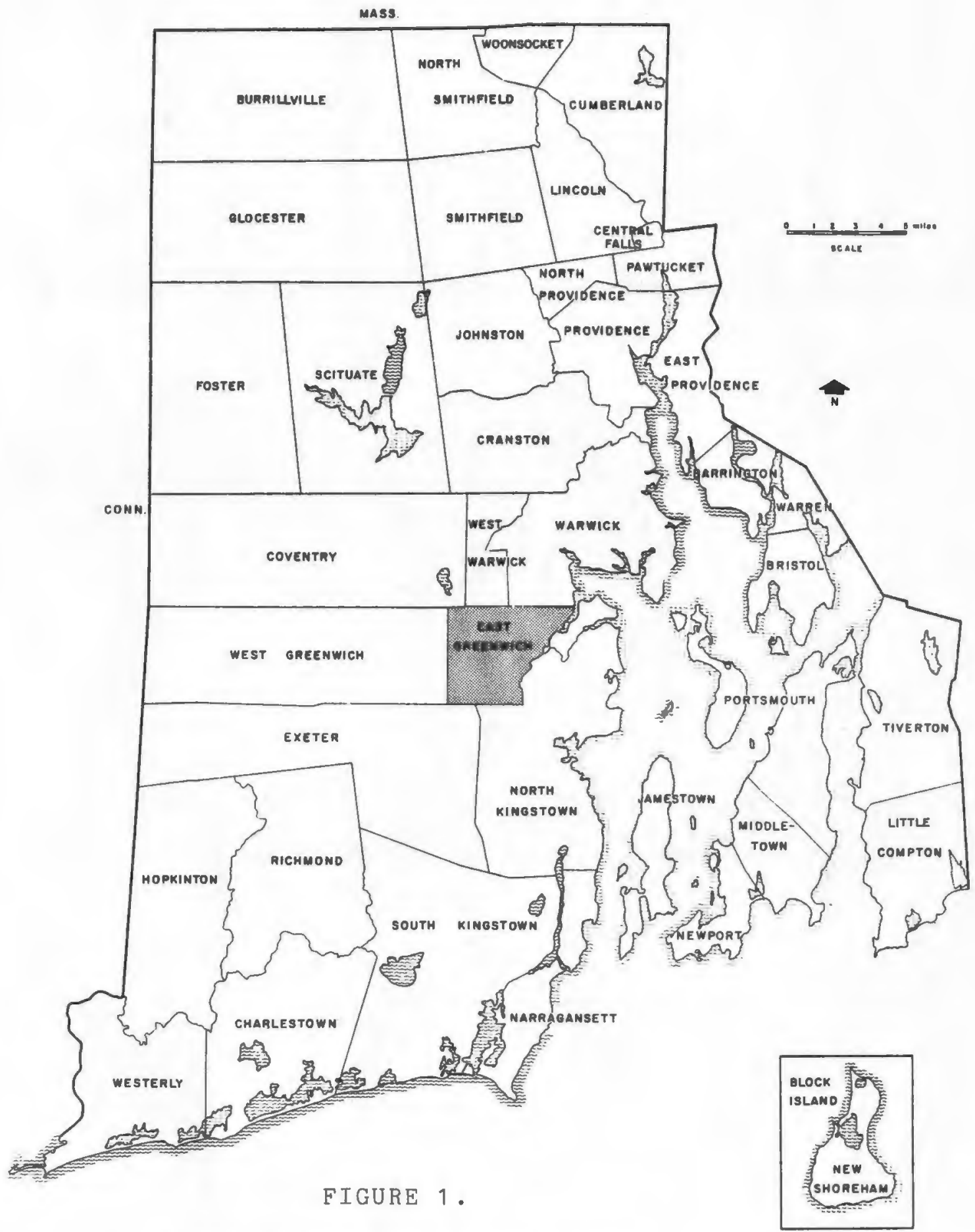

Rhode Island Cities and Towns 
activity. Table 4 is a breakdown of sales by location. This data indicates that sales of vacant land in the rural area west of Route 2 have been occurring throughout the period from 1963 to 1982, and have been increasing in proportion fairly steadily during that time. ${ }^{7}$ This supports James Brown's findings (1981) that sales activity will begin long before actual development, often as much as twenty years before development.

The price of land has also increased over the past twenty years. The average per acre selling price over the period 1963 to 1982 is shown in Table 5. Table 6 shows the changes in price per acre by area. In addition to the impact made on the price of land by its general location, the use or potential use of a parcel of land can also affect its price. Table 5 indicates that vacant land zoned for residential use commands a higher price than vacant land in general. This was true for all periods except 1970-1974. During this period there were five sales of high priced industrial land which skewed the results for the category of "All Vacant Land." Without these industrial land sales included in the analysis, the results of the time period 1970-1974 would be consistent with the others.

Table 6 indicates that land in the suburban neighborhood traditionally has been priced higher than rural land, but since 1980 this trend has shifted. Land in the rural neighborhood is now selling for significantly higher prices than land in the suburban neighborhood. This is due in part 
TABLE 5 .

AVERAGE PER ACRE PRICE OF VACANT LAND: 1963-1982

\begin{tabular}{cccc} 
& All Vacant Land & $\begin{array}{c}\text { Vacant } \\
\text { Residential Land }\end{array}$ \\
\cline { 2 - 3 } $1963-1964$ & $\$ 1,865 /$ ac & & $\$ 2,010 / \mathrm{ac}$. \\
$1965-1969$ & 2,089 & 2,112 \\
$1970-1974$ & 4,329 & 4,040 \\
$1975-1979$ & 6,787 & 7,013 \\
$1980-1982$ & 12,748 & 15,946
\end{tabular}


TABLE 6 .

AVERAGE PER ACRE PRICE OF VACANT LAND, BY AREA : 1963-1982

\begin{tabular}{|c|c|c|c|c|}
\hline & Urban* & Suburban & Rural & Al1 Land* \\
\hline $1963-1964$ & - & $\$ 3,563 / \mathrm{ac}$. & 562 & $\$ 1,865 / \mathrm{ac}$ \\
\hline $1965-1969$ & - & 3,634 & 1,197 & 2,089 \\
\hline $1970-1974$ & - & 6,394 & 3,670 & 4,329 \\
\hline $1975-1979$ & - & 8,199 & 6,390 & 6,787 \\
\hline $980-1982$ & - & 9,897 & 13,505 & 12,748 \\
\hline
\end{tabular}

* Only nine vacant land sales, of two acres or more, took place in the urban area of the town. This is not a large enough sample to be statistically valid or to accurately show land values in the urban area. The prices of urban land have been included in the totals for "All Land" in Table 6. 
to the high prices paid for lots in some of the newer more exclusive subdivisions west of Route 2. In the past, land prices have followed the traditional bid rent curve, but this has now been distorted by the attractiveness of "rural living" in a neighborhood setting, with urban type amenities such as public water, stormwater drainage systems, street lights and other street improvements. Because there are people who are able and willing to pay the price of a house in such a development, East Greenwich development patterns no longer follow the traditional bid rent model. Development has leapfrogged through the traditional evolutionary patterns and traditional means of controlling and directing development may not be as effective now as they were in years past.

The 352 land transfers studied in this investigation have been divided into two groups so that further analysis could be performed on parcels of varying size. The 116 parcels of ten acres or more in size were surveyed for environmental development limitations, their proximity to public facilities and their accessibility to shopping and major highway interchanges. The first test made was to determine whether the size of a lot affected its price per acre. The quantity in which a commodity is purchased usually does affect its per unit price due to economies of scale. Ordinarily, as quantity increases, per unit price decreases. Table 7 illustrates that lot size does affect per acre price as expected; the larger sized lots bring a 
TABLE 7 .

$\begin{array}{ccc}\text { AVERAGE PER ACRE PRICE OF VACANT } & \text { LAND, } \\ \text { BY LOT SIZE: } & 1963-1982 & \\ \begin{array}{ccc}2-9.9 \text { acre Lots } \\ \$ 2,515 / \text { ac. }\end{array} & \begin{array}{c}10+\text { acre Lots } \\ 2,721\end{array} & \text { Ratio } \\ 4,974 & 1,229 & 3.15: 1 \\ 8,467 & 2,005 & 2.21: 1 \\ 15,508 & 2,729 & 2.48: 1 \\ & 5,767 & 3.10: 1 \\ & & 2.76: 1\end{array}$


lower per acre price. The ratios given in Table 7 show that while small lots have been consistently more expensive per acre than large lots, the margin between the two has also been fairly consistent. The size of a lot does affect its price, but the influence of the variable "Lot size" has not changed significantly over the period of examination.

In many cases the smaller lots have been "improved" and are closer to being ready for actual building than the large lots which have yet to be subdivided. These "improvements" include such things as water and/or sewer lines, street grading and paving, partial clearing of lots, underground wiring of phone and electric utilities, and establishments of covenants and/or deed restrictions which will help preserve the "exclusive" character of the development.

of course there are other variables which may affect the difference in per acre price between large lots and small lots. For instance, many of the large lots studied are located west of Route 2 where sewer and water access is limited and the distance to downtown East Greenwich is obviously greater.

Lots of ten acres or more were analyzed to determine what impact the presence or absence of a certain characteristic has on the price of land. Parcels have been separated in this way for analysis because many of the smaller parcels have subdivision improvements (streets, utilities, land clearing, etc.l that can not be determined from the lot 
descriptions available. It is assumed that these improvements would add to the price of the land. Another reason for this division of data is the assumption made earlier that it is those market participants who deal in large quantities of land that have the greatest influence on the land market.

Four land characteristics have been selected for this analysis. Two are service amenities, public water and sewer availability; and two are environmental limitations on development, wetlands and soil suitability for septic systems. It has been shown many times in previous research that land development will follow the extension of public utilities such as water and sewer lines (Binkley et al. 1975, Tabors et al. 1976). The state and individual towns in Rhode Island, including East Greenwich, have passed restrictions on development in wetlands areas and on lot size, setbacks and other requirements for the installation of individual septic systems. The extent of wetlands in a lot, and the suitability of soils for septic system filter fields will help to determine the potential development possible on that site, and consequently will influence the price someone is willing to pay for that land.

Public water and Sewer

Tables 8 and 9 show that a parcel's proximity to public water and sewer lines affect its value. Between 1963 and 1972 , if public water lines were available on 


\section{TABLE 8 .}

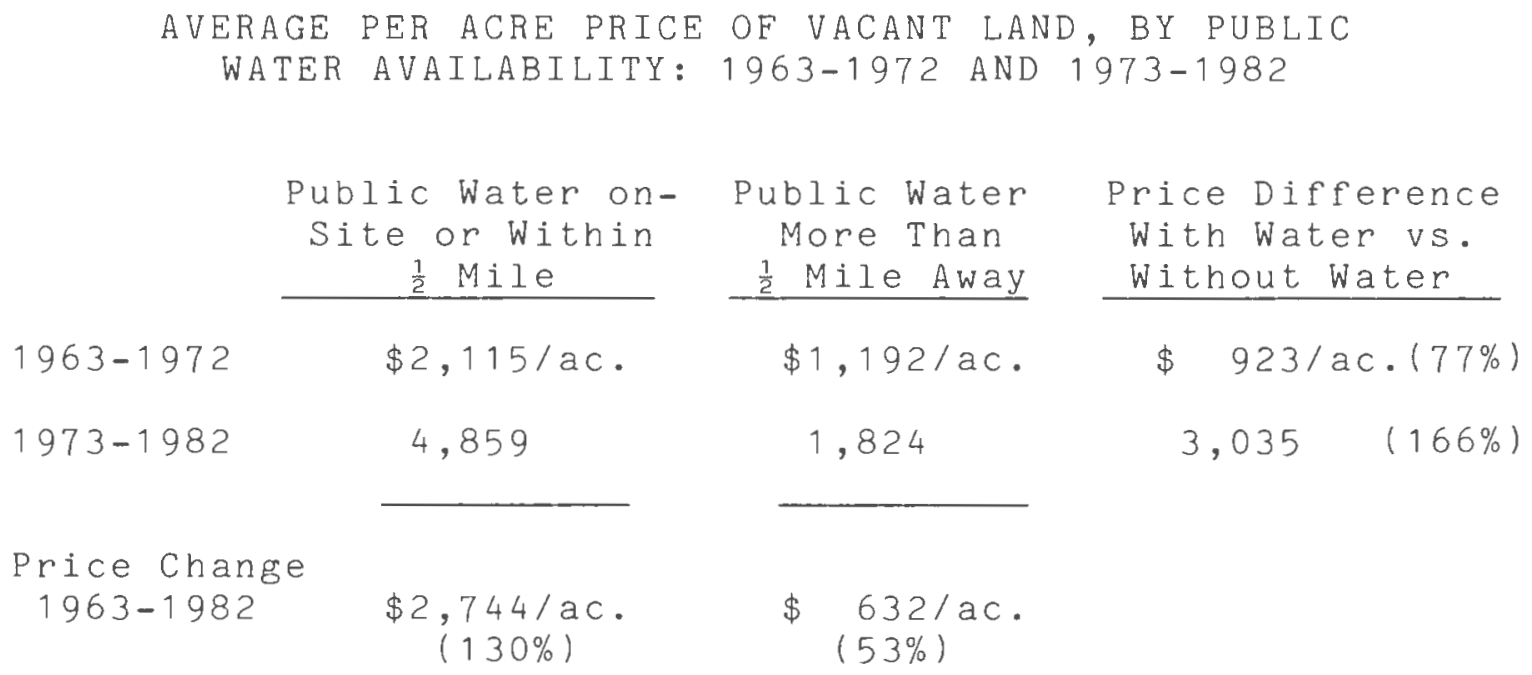

TABLE 9 .

AVERAGE PER ACRE PRICE OF VACANT LAND, BY PUBLIC

SEWER AVAILABILITY: 1963-1972 AND 1973-1982

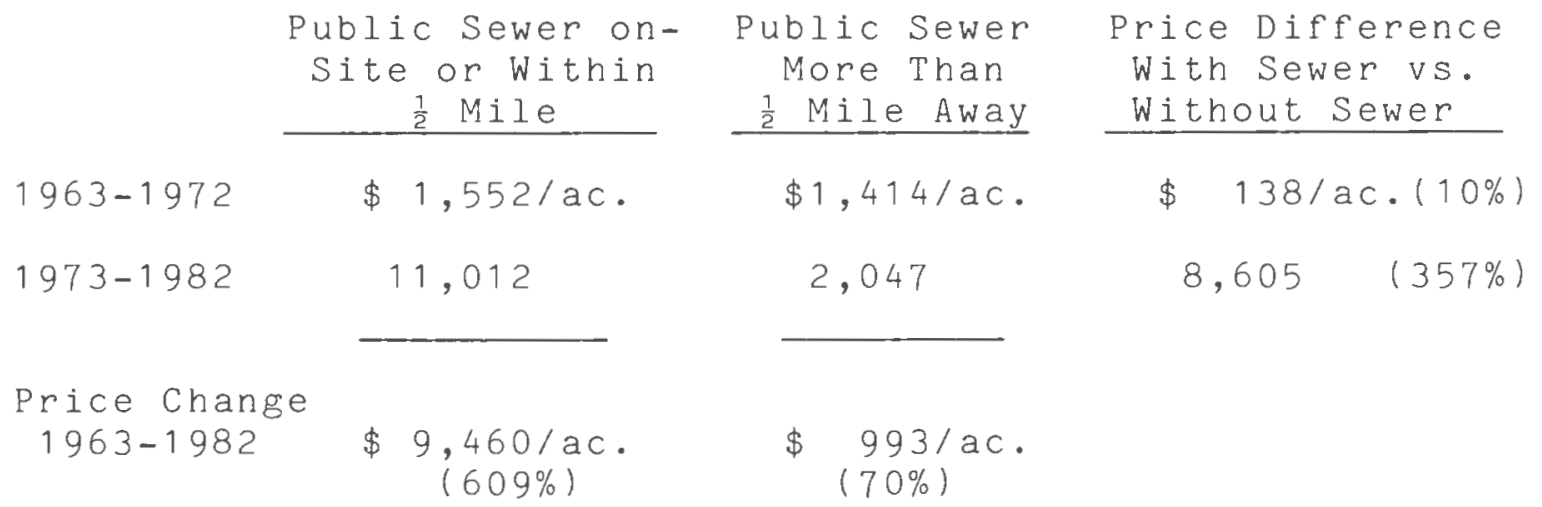


site or within one-half mile, the average price per acre was $\$ 923$ more than if public water was more than one-half mile away. The one-half mile breaking point was selected because this is about as far as a developer will extend water lines at his own expense.

The average per acre price of all land parcels, ten acres or more, for the ten year period from 1963 to 1972 was $\$ 1,420$. During the following ten year period, from 1973 to 1982 , the price more than doubled to $\$ 3,069$ per acre. The per acre price of land with public water accessibility almost tripled from the first ten year period (1963-1972) to the second (1973-1982). The per acre price of land without public water accessibility did not appreciate nearly as dramatically. The average per acre price of land with public water accessibility rose $\$ 2,744$ from the first ten year period to the second, while the average per acre price of land without public water accessibility increased by only \$632. A developer is willing to pay more for land with public water accessibility because it means that he does not have to invest in individual wells for each lot. Either way, the cost of public water hook-ups or the digging of private wells will be passed on to the homebuyer in the price he pays for his new home.

The importance of public water accessibility in determining land price also increased over the course of time studied. In the first ten year period, the average price differential between land with and without public 
46

water accessibility was $\$ 923$ per acre. In the second ten year period it rose to $\$ 3,035$ per acre. Even after inflation has been accounted for, this is a significant change in pricing. In the first ten year period, land with public water accessibility was, on the average, seventy-seven percent more expensive than land without. In the second ten year period it was 166 percent more expensive. Table 12 illustrates the price differentials for the four variables studied.

Only six cases in this study had public sewer lines on or near the site. For this reason, we can not be certain of statistically significant results. From the information available, it appears that those lots that were within onehalf mile of public sewer lines brought per acre prices more than three times those which were not. The price differential between sewered and non-sewered parcels was only ten percent during the first ten years, but jumped to 357 percent in the second. Again, these results must be considered with caution due to the small number of sewered parcels in the sample.

Wetlands

Tables 10 and 11 show that the extent of development limitations such as wetlands and soils unsuitable for septic systems do not appear to have an impact on the per acre price of land parcels ten acres or more in size. Land parcels with less than twenty-five percent of their 
TABLE 10 .

AVERAGE PER ACRE PRICE OF VACANT LAND, BY PROPORTION

OF LAND AREA IN WETLANDS: 1963-1972 AND 1973-1982

\begin{tabular}{|c|c|c|c|}
\hline & $\begin{array}{l}\text { Less Than } 25 \% \\
\text { in Wetlands } \\
\end{array}$ & $\begin{array}{l}25 \% \text { or More } \\
\text { in Wetlands } \\
\end{array}$ & $\begin{array}{l}\text { Price Difference } \\
\text { With Wetlands } \\
\text { vs. w/o Wetlands } \\
\end{array}$ \\
\hline $1963-1972$ & $\$ 1,487 / \mathrm{ac}$. & $\$ 968 / a c$. & $519 / \mathrm{ac} \cdot(54 \%)$ \\
\hline $1973-1982$ & 3,554 & 2,099 & 1,455 \\
\hline $\begin{array}{c}\text { Price Change } \\
1963-1982\end{array}$ & $\begin{array}{c}\$ 2,067 / \mathrm{ac} . \\
(139 \%)\end{array}$ & $\begin{array}{c}\$ 1,131 / \mathrm{ac} . \\
(117 \%)\end{array}$ & \\
\hline
\end{tabular}

TABLE 11 .

AVERAGE PER ACRE PRICE OF VACANT LAND, BY PROPORTION

OF LAND AREA WITH SEVERE SOIL LIMITATIONS:

1963-1972 AND 1973-1982

Less Than $\frac{1}{2}$ Area $\frac{1}{2}$ or More Area Price Difference

With Severe Soil With Severe with Soil Limitations

Limitations Soil Limitation vs. Without

1963-1972 \$1,537/ac. \$1,293/ac. \$ 244/ac.(19\%)

$\begin{array}{lllll}1973-1982 & 3,876 & 2,377 & 1,499 & (63 \%)\end{array}$

Price Change $\$ 2,333 / \mathrm{ac} . \quad \$ 1,084 / \mathrm{ac}$

$1963-1982 \quad(152 \%) \quad(84 \%)$ 
TABLE 12 .

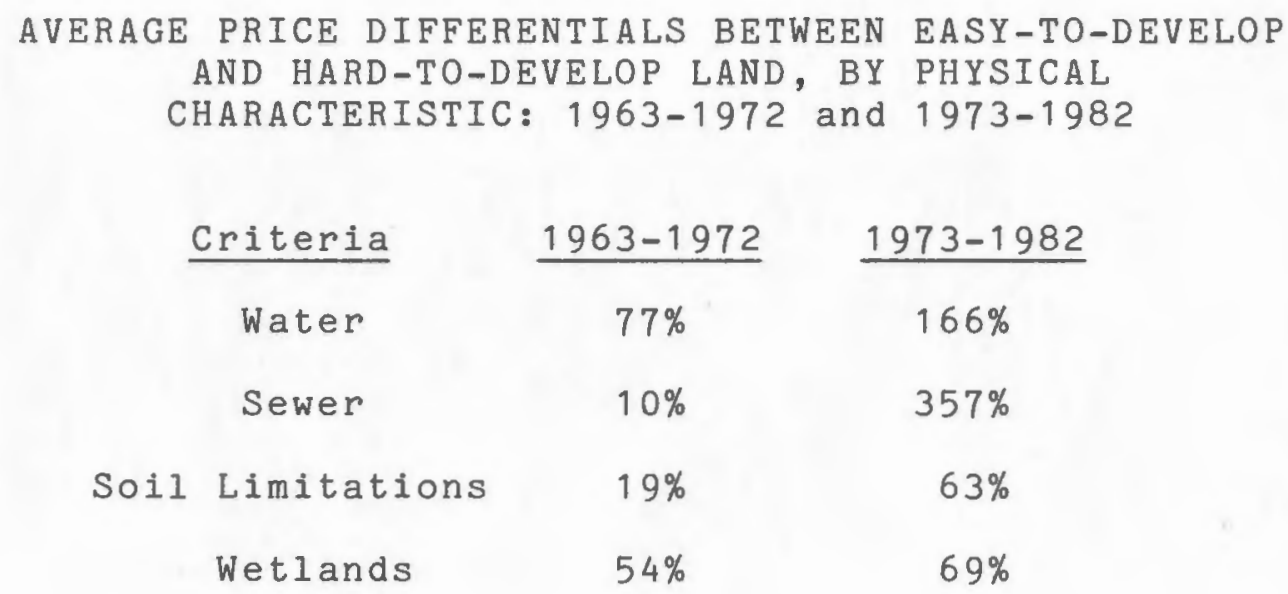


area in wetlands brought a much higher price on the land market than those with twenty-five percent or more of their area in wetlands. From 1963 to 1972, the difference in price between parcels with less than twenty-five percent wetlands and those with twenty-five percent or more was \$519 per acre, meaning that land without extensive wetlands was fifty-four percent more expensive. For parcels sold between 1973 and 1982 the difference was even greater, $\$ 1,455$ per acre, or sixty-nine percent more expensive for parcels with little or no area in wetlands.

As with water and sewer access, parcels that would be easier to develop, those with services available and few environmental limitations, became more valuable over the period of time studied. Parcels with less than twenty-five percent wetlands increased in per acre price by 139 percent from the first ten year period to the second. This is most likely due to more restrictive regulations on development in and around wetlands which were adopted on both the state and local levels.

Soils

Soil quality also appears to affect land values. If the soil composition is not suitable for ordinary septic system absorption fields and public sewers are not available, a developer must take into account the added cost of installing septic systems of a more elaborate design. In this way soil quality can play a role in determining the price 
of a particular parcel of land. Between 1963 and 1972, parcels with less than one-half of their land area in soil zones with severe limitations for septic systems brought an average of $\$ 244$ more per acre than those with one-half or more of their land area in severe soil limitation zones. This is a difference of nineteen percent. Tables 11 and 12 illustrate this. Between 1973 and 1982, this difference increased to sixty-three percent, or $\$ 1,449$ more per acre for parcels with fewer soil limitations. The value of land with few soil limitations increased by 152 percent from the first ten year period to the second. The value of land with extensive soil limitations increased by only eighty-three percent during that same time. In comparison, the value of all land in parcels of ten acres or more increased by 116 percent.

The above analysis illustrates that the limitations of wetlands, soil suitability, and proximity to public utilities such as water and sewer lines have a significant effect on the sale price of a piece of land. But the manner in which each of these analyses was made assumes that each of these factors is independent of all the others. What if this is not the case? The variables and the sample community selected for this study make such an occurrence quite possible. It can not be said, for example, that the availability of public water and sewer lines have no relation to one another, or that they have no relation to the 
distance between a particular lot and Main street. Figures 2,3 and 4 clearly show that water lines are extended to nearly all areas with public sewer service, and that generally those areas closer to Main Street are more likely to have water and/or sewer service than those some distance away. This phenomenon is referred to as multicollinearity, which means that the linear arrangements of one or more variables is somehow related to the linear arrangement of one or more others. Multicollinearities can be detected in several ways. Large coefficients in the correlation matrix always signal the presence of multicollinearities, though low correlation coefficients do not necessarily indicate the absence of multicollinearities. Correlation tables similar to those in Appendix B were used to determine instances of multicollinearity. Additional examples include such variables as "Year of Sale" with "Time Period," and "Distance to Main Street" with "Distance to Major Highway Interchange."

Thus, the next step in this study was to determine which variables were the most important in determining the price of a land parcel. This was done using correlation and regression analysis. Correlation and regression analysis ordinarily is performed in the following manner: Correlation tables are produced using all possible variables in the regression equation. All variables must be of interval or ratio order, as nominal and ordinal data will not work in a correlation and regression equation to give an accurate 
52

explanation of each variable's own influence on the equation. Those variables with large coefficients in the correlation matrix are checked for multicollinearity with other variables and eliminated if they are determined to be strongly multicollinear. Those variables with the lowest correlation coefficients are eliminated, leaving a selection of variables which presumably have the greatest influence on the dependent variable. Regressions can then be run to determine just how much influence each individual variable actually has on the dependent variable. In this particular case, traditional correlation and regression analysis is not appropriate. Some changes have been made in the method and the results should be considered as indicators only and not accurate reflections of the influence of each variable. The first step was to run a correlation matrix using all variables. This table is shown in Appendix B. Next, all invalid variables were removed from the equation. These include Plat and Lot number (these are nominal data used merely for identification of the parcels), and the variables "RT95" and "Shop" (these are just regroupings of the data for the variables "Distance to Highway" and "Distance to Main Street"). The variables remaining in the equation are as shown in Table 13. These variables were entered into the correlation and regression equation to see how influential they were in determining the per acre price of a parcel. The resulting tables are shown in Appendix B. The variable "Year of Sale" was entered into 
TABLE 13 .

VARIABLES USED IN CORRELATION EQUATION

\section{Variable Name}

Year of Sale (Deeddate)

Size of Lot (Lotsize)

Availability of Public Water (Water)

Availability of Public Sewer (Sewer)

General Zoning Category (Zoning)

Steep Slope Limitations (Slope)

Soil Suitability for Septic System Filter Field (Soils)

Distance to Main Street, East Greenwich Shopping and Civic Center (Distshop) Distance to Major Highway Interchange (DistRT95)

Per Acre Price (Peracre)

Wetlands (Wetland)

\section{Unit or Means of Measurement}

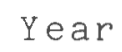
Farming

Presence or Absence of Slopes 15\% or more

Percent of Land Area With 'Severe'

$$
\text { Soil Limitations }
$$

Driving Distance, in Miles Driving Distance, in Miles, to Route 4 at Frenchtown Rd. or Division St. Sale Price + Lot Size, in Dollars

Percent Land Area in Wetlands 
54

the equation only for the entire twenty year period. When the data was broken down into five year periods for individual regressions, the variable "Year of Sale" became invalid for those analyses. The resulting correlation tables were used to determine which variables showed the closest correlation with the variable "Price Per Acre." For the twenty year period, the most important variables, those with the highest correlation coefficients are shown in Table 14. The availability of public water and sewer lines, and the year in which the sale took place were the most important variables. The importance of the year of sale is to be expected due to inflation; as time progressed, land prices increased. The importance of the availability of public water and sewer lines in this sample of land sales is consistent with other studies of land values and development potential (Brown 1981, Healy and Short 1981). Variables relating to environmental limitations on development showed the least correlation with per acre price.

When the data was broken down into five short study periods, and the same procedure run for each of these study periods, most of the same variables seemed to be important. They are listed in Table 15, by study period, in order of correlation strength. Keep in mind that the correlation coefficients given should be used as indicators only and not as exact values. The variable that appears most consistently as playing a role in determining per acre price is the availability of public water. This supports 


\title{
TABLE 14 .
}

VARIABLES WITH GREATEST CORRELATION TO PER ACRE PRICE : 1963-1982

\author{
$\underline{\text { Variable }}$ \\ 1. Availability of Public Sewer \\ 2. Year of Sale \\ 3. Availability of Public Water \\ 4. Zoning Category \\ 5. Distance to Main Street
}

Correlation Coefficient .550

.490

.456

.283

$-.273$ 
TABLE 15 .

VARIABLES WITH THE GREATEST CORRELATION TO PER ACRE PRICE, BY TIME PERIOD: 1963-1982

\begin{tabular}{|c|c|c|c|c|c|}
\hline \multicolumn{2}{|c|}{$1963-1964$} & \multicolumn{2}{|c|}{$1965-1969$} & \multicolumn{2}{|c|}{$1970-1974$} \\
\hline Variable & $\begin{array}{l}\text { Correlation } \\
\text { Coefficient }\end{array}$ & Variable & $\begin{array}{l}\text { Correlation } \\
\text { Coefficient }\end{array}$ & Variable & $\begin{array}{l}\text { Correlation } \\
\text { Coefficient }\end{array}$ \\
\hline Water & .773 & Distshop & -.458 & DistRT 95 & -.540 \\
\hline DistRT 95 & -.575 & Zoning & -.358 & Distshop & -.480 \\
\hline Lotsize & -.359 & DistRT 95 & -.283 & Wetland & .352 \\
\hline Wetland & .346 & Water & .245 & Lotsize & -.305 \\
\hline Soils & .251 & Soils & .251 & Water & .250 \\
\hline
\end{tabular}

TABLE 15 -- Continued.

\begin{tabular}{|c|c|c|c|}
\hline \multicolumn{2}{|c|}{$1975-1979$} & \multicolumn{2}{|c|}{$1980-1982$} \\
\hline Variable & $\begin{array}{l}\text { Correlation } \\
\text { Coefficient }\end{array}$ & Variable & $\begin{array}{l}\text { Correlation } \\
\text { Coefficient }\end{array}$ \\
\hline Sewer & .572 & Sewer & .823 \\
\hline Water & .469 & DistRT 95 & -.654 \\
\hline Distshop & -.212 & Water & .432 \\
\hline Wetland & -.198 & Lotsize & -.425 \\
\hline Zoning & .157 & Zoning & -.321 \\
\hline
\end{tabular}


previous analyses of residential growthin East Greenwich (Loranger 1974). Other important variables are "Distance to the Highway," "Distance to Main Street, East Greenwich," and since 1975, the "Availability of Public Sewers." The relationships between per acre price and the availability of public water and sewer are positive ones, while the relationships between per acre price and distance to the highway and Main Street are negative ones. This means that, generally, as accessibility to water and sewer increase, so does per acre price; and as distances to the highway and Main street increase, per acre price decreases. This is consistent with the findings shown in Table 6 of per acre price by neighborhood. The further a parcel is from the urban center of town, and the less urban (or more rural) the neighborhood, the lower the price per acre. The exception to this is the period 1980 to 1982 where per acre price in the rural neighborhood exceeded that in the suburban neighborhood. While distance to shopping and Main Street was no longer one of the five most important variables, as determined by correlation analysis, for this latest time period, distance to the highway was an important variable. In addition to having some attractive urban and suburban type amenities, the lots in the new "exclusive" residential subdivisions have highway access points within a few minutes driving time. For the executive who moves to East Greenwich in order to enjoy the combined advantages of rural and suburban living, this highway access is an 
important feature. It means that he can get to work in less time than it would take from some other rural/suburban areas.

Land Use Regulations

One of the purposes of this investigation was to determine whether or not land use regulations have had an impact on the land development process. In order to determine whether or not land use regulations have had any influence on the importance of the variables studied in determining the price of land, land use regulations were reviewed to determine when changes were made that might influence land prices.

Zoning is the regulation of the use of land and structures, which are privately owned, for the general welfare of the people. The regulations are made with the purpose of promoting the public health, safety, morals and general welfare of the people. The authority to enact zoning regulations lies in the police power of the state. The power rests with the state and no municipality or other subdivision of the state may enact a zoning ordinance until permission is given by the state through a legislative act. The cities and towns of the state of Rhode Island have been given permission to enact zoning ordinances by the general Enabling Act (G.L.R.I. 45-24), or by special enabling acts for specific towns. A zoning ordinance was first adopted in East Greenwich in 1935.8 
59

Major revisions were enacted in 1960; Industrial Performance Standards were added in 1968; a Sign Ordinance was adopted in 1969; and regulations regarding the development of wetlands were tightened in 1971. Minor changes have been made since that time, but major changes are not expected until some time in 1984 when the Planning Board presents its suggested revisions of the ordinance to the Town Council. Of course, zoning map changes have been made during the twenty year period from 1963 to 1982, but most of these have concerned individual lots only. The "general Zoning Category" information collected for each sale is the "Use Category" at the time of sale, as determined by the East Greenwich Tax Assessor's Office. (Appendix A is a sample of the Sales Abstract completed by the Assessor's Office at the time of each sale.)

While conventional zoning normally applies to individual lots, subdivision regulations govern the process by which these lots are created out of larger tracts. The purpose and nature of subdivision regulations have changed over the course of their evolution to address the changing issues of land development. While their function has changed, their definition has remained "the control by a public authority of the platting and conversion of raw land into building lots." (Yearwood 1971)

$$
\text { Adoption of subdivision enabling legislation in }
$$

Rhode Island was suggested in the 1930's (Cady and Menhincih 1937), with the reason that there was a need to 
regulate the future character of the cities and towns in the state. The Rhode Island state legislature adopted subdivision enabling legislation in 1945 (G.L.R.I. 45-23) and subdivision regulations were adopted in East Greenwich in 1963.9 The state enabling legislation gave the town councils the right to appoint a board to review subdivision proposals. In the Town of East Greenwich, the Town Council has reserved this responsibility for itself and so also sits as the Platting and Subdivision Board. The Planning Board, Conservation Commission, Development Commission, and when applicable, the Historic District Commission serve as advisory review boards to the Platting and Subdivision Board in the review of subdivision proposals. While zoning determines the general use in which a parcel of land may be developed, subdivision regulations place more specific guidelines on development specifications. Subdivision regulations control such development articles as grading, drainage, streets and utility improvements, performance bonding and the dedication of recreation land. Most of the regulations presently in effect were included in the original 1963 version of the East Greenwich Subdivision Regulations, though there have been minor expansions of regulatory control in some areas during the past twenty years. These include regulations regarding the installation of swimming pools adopted in 1970; stricter specifications to prevent soil erosion in 1975; and requirements that all utilities be placed underground and 
streetlights be provided by the developer as adopted in 1976. Requirements regarding land to be dedicated for recreation were adopted in 1977 , the same year in which a preliminary plat approval stage was added to the subdivision application process. While there have been no major changes to zoning or subdivisions that might cause drastic changes in development patterns, the continuing review and updating process has given the town more control over the sorts of development taking place.

One of the objectives of this study was to determine the impact of land use regulations on land development in East Greenwich. Development patterns during the first and second ten years of the study period will be examined next in an attempt to identify any changes that might be the result of more restrictive land use regulations. Land parcels with public water and/or sewer on site or within one-half mile were more likely to be developed during the twenty year study period. Land use regulations in East Greenwich encourage connection with public water and sewer lines by requiring it whenever possible. In order to satisfy this requirement, and reduce the costs of development, developers are likely to find land with utility accessibility more desirable for development. Of the 116 parcels of ten acres or more sold between 1963 and 1982, forty-one were also developed during the same twenty years. The date of development was determined to be the date of Preliminary Plat Approval for the first phase of devel- 
opment on that particular parcel. Sixteen of these parcels had no water or sewer within one-half mile, while twentyfive had one or the other within one-half mile. The development rate for parcels with neither utility within onehalf mile was twenty percent, while the development rate for parcels with at least one utility within one-half mile was seventy-one percent. The development rate for parcels with one utility on site, or both water and sewer within one-half mile, was seventy-nine percent. Table 16 shows the number of developed parcels by public facility accessibility

Land parcels with no environmental limitations to development were more likely to be developed than those with some limitations. This is most probably due to environmental and economic awareness on the part of developers and to land use regulations regarding land with environmentally sensitive qualities. Fifty-two percent of those parcels with no wetlands, no steep slopes, and no soils with severe limitations for septic systems were developed during the twenty year period. Only thirty-one percent of those parcels with any of these limitations present, in any amount, were developed. Table 17 shows the number of developed parcels by presence of environmental development limitations.

Land sold before 1973 generally had better access to public utilities (water and sewer) and fewer development limitations (wetlands, steep slopes and poor soils) 
TABLE 16 .

NUMBER OF DEVELOPED PARCELS, BY PUBLIC FACILITY ACCESSIBILITY: 1963-1972 AND 1973-1982

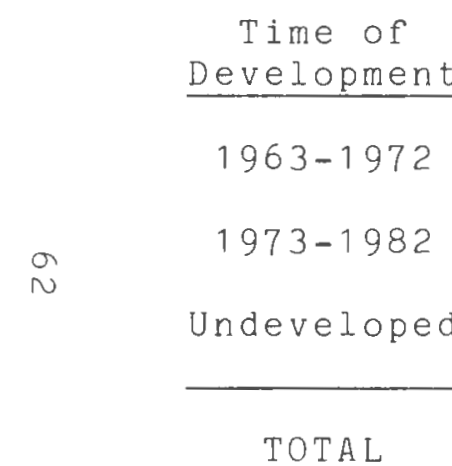

TOTAL

No water or Sewer
w/in $\frac{1}{2}$ Mile
5
11
65
81

Water or Sewer w/in $\frac{1}{2} \mathrm{Mile}$

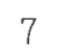

3

6

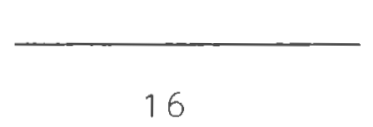

Water or sewer on Site or water and Sewer $\overline{\bar{W}}$ / in $\frac{1}{2} \mathrm{Mil}$

\begin{tabular}{cr}
5 & 17 \\
10 & 24 \\
4 & 75 \\
\hline 19 & 116
\end{tabular}


TABLE 17 .

NUMBER OF DEVELOPED PARCELS, BY PRESENCE OF ENVIRONMENTAL DEVELOPMENT LIMITATIONS:

1963-1972 AND 1973-1982

Time of No wetland, Slope
orelopment

Development

$1963-1972$

$1973-1982$

Undeveloped

TOTAL
9

3

11

23
Wetland and/or Slope and/or Poor Soils

8

21

64

93

Total

17

24

75

$\frac{64}{93}-\frac{75}{116}$


64

than land sold after 1973. This is most likely an indication that the actors in the land market before 1973 were well aware of the advantages and disadvantages of public utility access and environmental limitations on development and purchased land accordingly. By the second ten years of the study, much of the "better" land had entered the land investment and development stages, leaving only the land further away from utilities, and often land with more development limitations for those actors entering at the later dates. 


\section{CHAPTER FOUR}

In the preceeding chapter, the effects of various land characteristics have been documented as they relate to land prices in East Greenwich, Rhode Island. This chapter will attempt to synthesize these results and develop conclusions regarding the research questions set out in the beginning of this paper. Finally recommendations for alternative land use controls are suggested which will address the needs of the developer, the homebuyer and the community alike.

This study was conducted with two purposes in mind: first, to examine the characteristics of the land market; and second, to determine the relationship between land market activities and land use controls. The study reveals that a variety of factors help to determine the price of a particular land parcel, including physical and environmental characteristics, locational characteristics and service amenities. While at the outset of this study it was hypothesized that significant changes in land use regulations would result in dramatic changes to the land market, it appears that it was the developmental characteristics of the land itself that produced the most noticeable differences. The increasing margin between land with and without certain developmental characteristics appeared to be the largest single influence on land prices. 
As suggested in the previous chapters, the "Land Market" is a result of the many decisions made by individual land market participants, with land price determinations a function of supply and demand. Supply and demand also interact through the land market to determine not only the price for which land will be sold, but also the amount of land available for transfer. While the physical amount of land in existence will always remain constant, land supply in the economic sense varies constantly. Variations in the amount of land available for particular uses are a function of the natural characteristics of the land, technology, economic opportunities and institutional constraints. Variations in the amount of land offered for sale are a function of price, demand, willingness to pay, desires and values of existing owners, and demographic factors affecting those owners. Land demand is a function of population growth, migration, economic growth, interest rates, travel and energy costs, market expectations and the availability of attractive alternative investments. This study has taken an in-depth look at supply functions such as natural characteristics of the land, institutional constraints and price. Information regarding population dynamics, housing statistics and building trends provides a background for the supply data gathered.

The empirical findings of this study provide an illustration of some of the factors affecting the dynamics of the land market in East Greenwich. While many of these 
findings seem logical, or even obvious, their quantification has some practical benefits. The amenities of public utilities and access to transportation systems are important characteristics in determining the worth of a piece of land, as are the absence of environmental constraints such as wetlands and poor soils.

The first step of this study was to assemble some background information on population and housing dynamics in East Greenwich. From this it was determined that growth in East Greenwich followed patterns similar to those in other urban fringe communities: rapid growth in the postwar periods, peaking in the $1960^{\prime} \mathrm{s}$. The growth rates in East Greenwich may have been somewhat exaggerated by the Navy activity in North Kingstown, but it is difficult to determine just how much was due to the added Navy personnel.

Land in East Greenwich has fewer environmentally

related limitations than in some neighboring communities. It lacks extensive shoreline, salt marshes and coastal ponds, large inland water bodies or extensive public water supply watersheds. As discussed in Chapter Three, only a small part of the town is in wetland areas, and only about half of the land area is unsuitable for individual septic systems. Public utility service amenities are limited to a small area of the town but are even more limited in communities to the south and west of East Greenwich. Until 1970, development in East Greenwich was concentrated east of Route 2 in the urban and suburban areas. Land 
sales activity was taking place in the rural areas west of Route 2 during this time, but there was little actual building until the $1970^{\prime} \mathrm{s}$. Throughout the $1970^{\prime} \mathrm{s}$ land west of Route 2 continued to bring lower prices on the land market than land in the urban and suburban areas, but since 1980 this trend has been reversed and parcels in the rural areas are now priced well above those east of Route 2 . Most of the new subdivision activity is taking place west of Route 2 , and much of it is for large lot, upper income housing. These "exclusive" developments have become very attractive to the "executive set." The high prices that people are willing to pay for these homes have made East Greenwich a popular place for real estate investment. In the past fifteen years the inflation of residential land prices in East Greenwich has out-stripped the Consumer Price Index for housing by a margin of three to one (U.S. Bureau of Labor Statistics 1967 through 1982).

This shift in pricing patterns represents a departure from the traditional bid rent model. Distance to the urban center of town is no longer a strong determinant of price. Distance to the highway, the link to regional shopping and employment, is now more important. This is an indication that East Greenwich is losing its character as a selfsufficient and independent community. People who are moving to the new developments are not drawn to shopping and employment centers in East Greenwich, but to those of a wider region. This is a typical trend in communities that were 
beyond the urban commutershed, but with advanced communications and transportation systems have been consumed by the urban region. People now find it easier to shop at regional malls than in downtown East Greenwich and employment prospects for members of the executive class are more profitable in Providence, Cranston and Warwick which are now only a short drive away.

The results of the survey support the assumption that dry land, with minimal soil limitations and close proximity to public utilities is more valuable than swampy land with severe soil limitations and no feasible access to public utilities. Popular theory holds that the three essential elements in the process of suburbanization and land development in the United States are highways, water supply and sewerage (So et al. 1979). As illustrated by the price differentials shown in Table 12 , the presence or absence of public water and/or sewer lines has a significant impact on the price of a parcel of land, a much stronger impact than either the presence of wetlands or suitability of soils for septic systems. Over the course of time studied in this analysis, the presence or absence of these public utilities became increasingly influential in determining land prices. This not only supports the popular theory mentioned above, but reflects the critical importance of those public policies which link public water and sewer systems to future land development. Perhaps it also a reflection of the new homebuyer's resistance to taking on 
the risk of a private well and an individual sewage disposal system when he could find a similar home with public services.

In any case, it is clear that the presence of public utilities does add significantly to the value of a parcel of land, and it appears likely that this is partly a result of current municipal land use regulations which require public utility hook-ups wherever feasible. Consequently, tighter restrictions on development in areas without public utility lines might well be an effective means of discouraging scattered and poorly planned development in rural areas, with the concomital benefits of agricultural land and open space preservation, and reduced municipal service and capital costs to the community. In addition, the results of this study demonstrate that land values are very sensitive to environmental constraints on development, such as wetlands and soil quality. While these factors do not play as strong a role in determining land values, their impact does indicate that land investors and developers are aware of these limitations, both because of their direct impact on development potential and because of institutional restrictions placed on the development of such areas by state and local governments. These regulations have been effective in limiting development in wetlands areas and in areas where soils are illsuited for septic system operation. In this way they have been an effective means of preserving natural areas, wild- 
life habitats, and water quality. These regulations also affect the fiscal well-being of a community by helping to prevent flooding accidents and public health hazards.

The patterns and characteristics of land sales and development in East Greenwich indicate that site characteristics are very important determinants of price, moreso probably than land use controls such as zoning and subdivision regulations. The land market in East Greenwich requiresone and two acre lots for residential development west of Route 2. In many communities, large lot zoning is used as a deterrent to rural residential sprawl. But because the land market in East Greenwich is such that these Iarge lots are in demand, this type of zoning is not an effective deterrent to scattered residential development in this town. Further, residential land uses are allowed in all zoning districts in East Greenwich. Capital improvements such as public utilities are directing growth in East Greenwich now. Lot selection for development is determined by the availability of public utilities, water especially. Therefore, it can be concluded that land use and development might best be controlled by regulations that relate to capital improvements. Once the town has determined where it feels development is most desirable, and the density levels appropriate, it can then initiate capital improvement projects in these areas and adopt land use controls that direct development toward these areas and discourage it in others. 
There are two techniques used by communities to control and direct growth in this manner. The first is direct regulation through zoning and subdivision ordinances; the second is indirect regulation through policy decisions. This includes decisions regarding the location and extent of public utility services, particularly water and sewers. These policies have an indirect effect on development because they do not dictate where development can occur, but where facilities will be provided. "Public Utility Land Use control" can and should be used as an integral part of the land use control and development program for the Town of East Greenwich. Rhode Island planning enabling legislation grants municipalities the power to control the direction and timing of public utility extensions as a land use tool to meet the objectives of the comprehensive plan as long as it is coordinated with other planning tools such as zoning and subdivision ordinances.

The character of future development in East Greenwich has been determined somewhat by past development. In the past twenty years, East Greenwich has become a popular uppermiddle class community. It is likely that in the future East Greenwich will attract more of the same type of people and in response, the development market will produce more of the same type of homes. East Greenwich can continue to attract upper-middle class residents and $\$ 150,000$ homes to satisfy them, but it is not necessary to scatter these developments haphazardly across the landscape. 
73

Land use controls that direct development to areas with public utility access and provide flexibility in design can help to produce developments that require fewer municipal capital improvements, fewer subdivision improvements by the developer, and preserve open space and agricultural land in the rural sections of town. Such concepts as cluster development allow flexibility in design that can result in conservation of environmental and economic resources while providing residents with open space around their homes that gives them the feeling of openness that they seek in a rural setting. The open space in a cluster development is protected in perpetuity, unlike open fields and woodlands around a conventional subdivision that can be sold and developed at any time regardiess of the wishes of the subdivision residents.

The Comprehensive Community Plans of 1966 and 1972 suggested as a capital facilities goal that:

Water facilities should be extended as far as economically feasible into the western portion of the Town, at a progress rate determined by the demands for development within the area.

This indicates a policy of allowing development to direct public facilities. Fortunately this has not proved to be as costly a policy for the Town of East Greenwich as it has for other communities. In the 1982 version of the Plan, this goal has been revised to read as follows:

Expansion of the water system to western part of the Town should be considered only as far as practical and economically feasible. 
74

Included in the stated objectives of the current Comprehensive Community Plan (1982) are the following:

- To provide residential areas which will permit a wider range of housing types in a safe healthful environment.

- To provide adequate open space, outdoor recreation and other facilities.

- To insure that plans and programs proposed are within the financial capabilities of the Town, and to utilize the resources of the community as efficiently as possible.

- To control residential development at a level which can be efficiently accomodated by public services.

This last goal indicates that East Greenwich has approached the issue of capital investment and its relation to development. The groundwork has been laid in the Plan, but the corresponding ordinances must now be reviewed and revised to insure conformity with the Plan. In 1984 , construction will begin on a water line extension between Division and Frenchtown Roads. This line will increase capacity of the system, as well as connect previously unserviced areas. It can be expected that development will follow shortly. Once this line is in operation, only about twenty percent of the Town will be more than one-half mile from a public water line. It is important that the Town adopt policies and corresponding regulations to protect this twenty percent from unplanned and unwanted development.

The Town needs to adopt zoning and subdivision regulations that will address development on both townwide and 
and individual development levels. In order to minimize additional municipal costs for things like collector street improvements, school busing, police and fire protection, and water and sewer lines, and to protect the valuable natural and agricultural resources found in the western part of town, the Town should adopt a policy that would encourage development in areas closer to the developed part of town where utilities are already available and streets are already laid, rather than in heretofore undeveloped open spaces. On the level of individual developments, cluster ordinances are a policy option. Performance standards are another flexible approach to zoning. These are particularly effective in handing the issues of the environment, the capacity of public facilities, and compatibility with sites surrounding a new development. The Town of East Greenwich has some familiarity with performance standards as they are used in evaluating industrial development proposals already.

The more innovative approaches to land use control, such as performance standards and cluster zoning are seen by many as more appropriate systems in rural areas (Lefaver 1978, Getzels and Thurow 1979). Lefaver calls traditional zoning "one of the most unresponsive planning tools to changing situations," because it forces government to impose unrelated and often unnecessary regulations in many areas to achieve specific purposes in a few. And once land is zoned for one or two acre lots, what is there to prevent it 
76

all from being developed in such a way, unless land use regulations specifically relate to other controls such as public utility connections? This sort of trust in the economic forces of the land market puts development in the hands of the land market and not in those of the town which will ultimately have to support that development. Based on the results of this study, it appears that the Town of East Greenwich could significantly benefit from a review of its development history and its land use policies and regulations. Clearly traditional zoning has not been effective in directing growth in East Greenwich. The market is such that more innovative controls will be necessary to prevent the fiscal and environmental problems resulting from rural sprawl in the future. A clear public utility extension policy, stricter regulations regarding hook-ups for new developments, and allowance for design flexibility in development can help to protect the Town's natural, economic, social and historical resources. Equally important, they can help to preserve the reputation of East Greenwich as a good place to live. 


\section{FOOTNOTES}

1 Because of limitations in state enabling legislation, Rhode Island communities have relied on zoning, subdivision regulations and building codes to direct development. Recently, some communities have begun to experiment with more innovative approaches within the framework of their zoning and subdivision regulations but this has been a long time in coming and it will be a long time yet before such ideas receive widespread public acceptance.

2 Rhode Island is an exception to this and is discussed at a later point in this chapter.

3 At this writing, the Rhode Island League of Cities and Towns, in cooperation with other planning professionals in the state, is working to prepare new enabling legislation to remedy this problem of non-conformance.

4 This illustrates the national trend toward smaller households, though East Greenwich still has a larger average household size than does the state as a whole.

5 Whether this turnaround in growth rates is the result of land use regulation, a population anomoly such as the Navy pullout in 1973, or some other factor remains to be explained. It is likely that it was caused by a combination of events and circumstances, many of which are beyond the scope of this study.

6 As East Greenwich became more attractive to upper income groups, new home buyers were probably more willing to absorb the cost of extending public utilities to other parts of town. This can not be quantifiably shown with the data used in this study, but the concept has been expressed by both developers and public officials.

7 For the purposes of this study, Route 2 will be used as the dividing line between rural and suburban areas. Route 2 was selected because it is also a dividing line between plats. The Loranger study used Route 4 as the dividing line between rural and suburban areas. Route 4 parallels Route 2 about two thousand feet to the east, and while there is an area of land between the two highways, it should not have enough of an impact to distort comparison of this study with the Loranger study. 


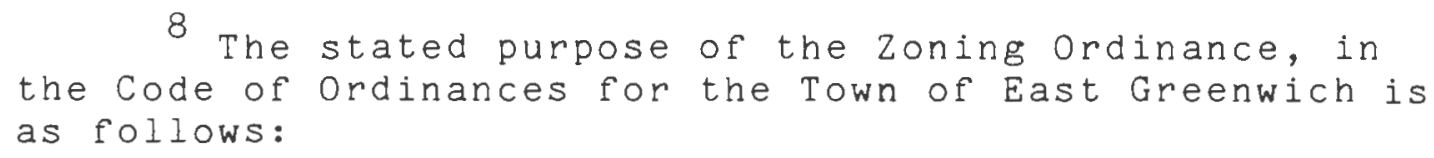

\title{
APPENDIX A
}

ZONING*

\section{ARTICLE I. INTRODUCTION}

\section{Section 1. Purpose.}

The zoning regulations and districts herein set forth have been made in accordance with a comprehensive plan for the purpose of promoting the public health, safety, morals, and general welfare of the town. They are designed to lessen congestion in the streets; to secure safety from fire, panic and other dangers; to provide adequate light and air; to prevent the overcrowding of land; to avoid undue concentration of population; and to facilitate the adequate provision of transportation, water, sewerage, schools, parks and other public requirements. They are made with reasonable consideration, among other things, of the character of each district and its peculiar suitability for particular uses, and with a view to conserving the value of buildings and encouraging the most appropriate use of land throughout the town.

9 The stated purpose of the Subdivision Regualtions, in the Code of Ordinances, for the Town of East Greenwich is as follows:

\section{APPENDIX B}

\section{SUBDIVISION REGULATIONS*}

\author{
Part I. Residential Development
}

\section{ARTICLE I. AUTHORITY AND PURPOSE}

\subsection{Authority.}

These regulations are adopted by the East Greenwich Platting and Subdivision Board pursuant to the authority vested in it by Title 45, Chapter 23 of the General Laws of Rhode Island, 1956, as amended, and Chapter 22 of the Code of Ordinances of the town. 


\subsection{Purpose.}

The purpose of these regulations is to make adequate provision for traffic; to lessen traffic accidents; to promote safety from fire and other dangers; to provide adequate light and air; to prevent overcrowding of land; to prevent the development of unsanitary areas for housing purposes; to secure a well articulated street and highway system; to promote coordinated development of unbuilt areas; to secure an appropriate allotment of land area in new developments for all the requirements of community life; to conserve natural beauty and other natural resources; to conform to the master plan of the town as the same may be amended from time to time; to furnish guidance for the wise and efficient expenditure of funds for public works; and to facilitate the adequate, efficient and economic provision of transportation, water supply, sewerage, recreation and other public utilties and requisites.

10

Lots in the stone Ridge development in East Greenwich are currently being sold for about $\$ 30,000$ an acre. Most finished homes, built on one acre lots in this development are selling for $\$ 140,000$ to $\$ 170,000$. This means that land prices make up as much as twenty-one percent of the final cost of housing in this area. The estimated builder's cost of new home construction in this area is $\$ 85,000$ to $\$ 110,000$.

1 A recent development of eight homes in East Greenwich incurred the costs shown below, from the Town. This development was only one section of a Iarger development plan.

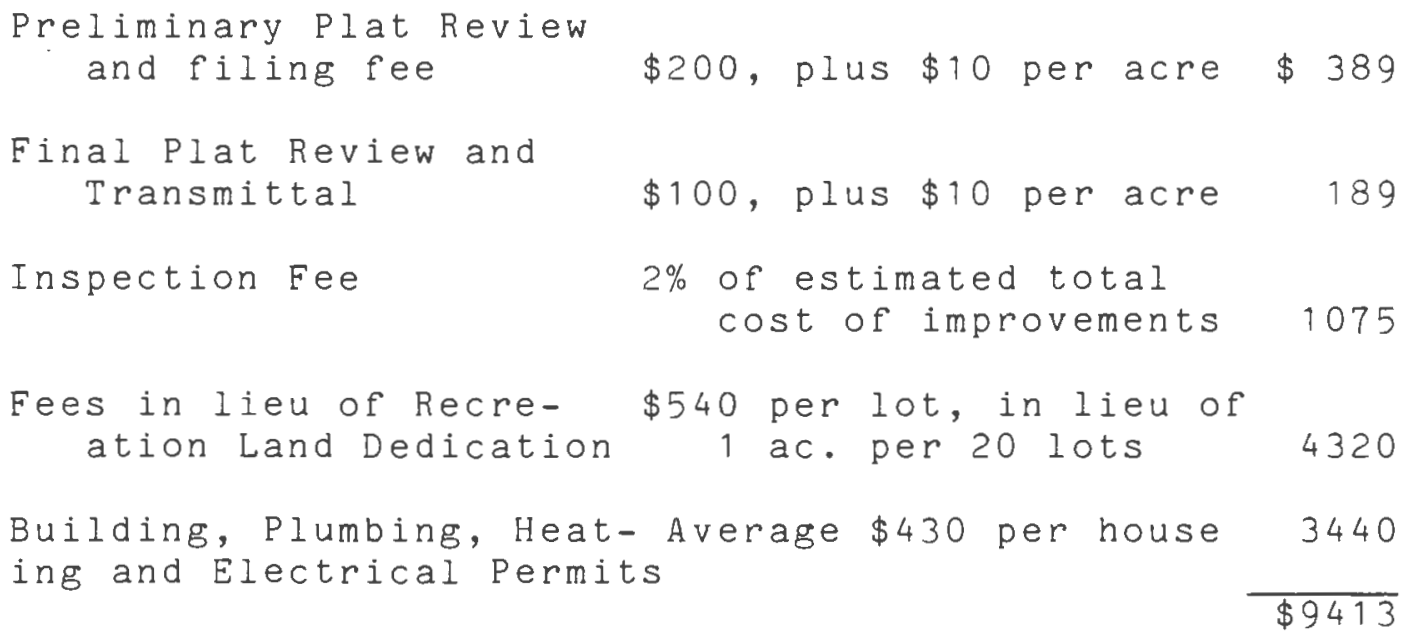


80

$$
\begin{array}{ll}
\text { Plus: Deeds and Mortgages } & \$ 10 \text { first page, plus } \\
& \$ 1 \text { each additional pg. } \\
\text { Restrictions and Covenants } & \$ 6 \text { first page, plus } \$ 1 \\
& \text { each additional page } \\
\text { Performance Bond* } & \$ 53,750
\end{array}
$$

* If the developer desires final acceptance of his plat prior to completion of construction of improvements specified in the Subdivision Regulations, a performance bond must be posted in an amount sufficient to cover the cost of such improvements and must be conditioned on the completion of such improvements within two years of the date of the bond. Upon completion of the improvements the developer may apply for release of the bond. If the Town Engineer approves the improvements, the bond is released to the developer. 
SALSS ABSTRACT D-1 (AEV. 12-02) 1SE
Instructions

MTAN mmTt COPY; FOMWAED EUFF TO DEPATIEAT Of COMMUNTY AFf AIS ice washictonst.

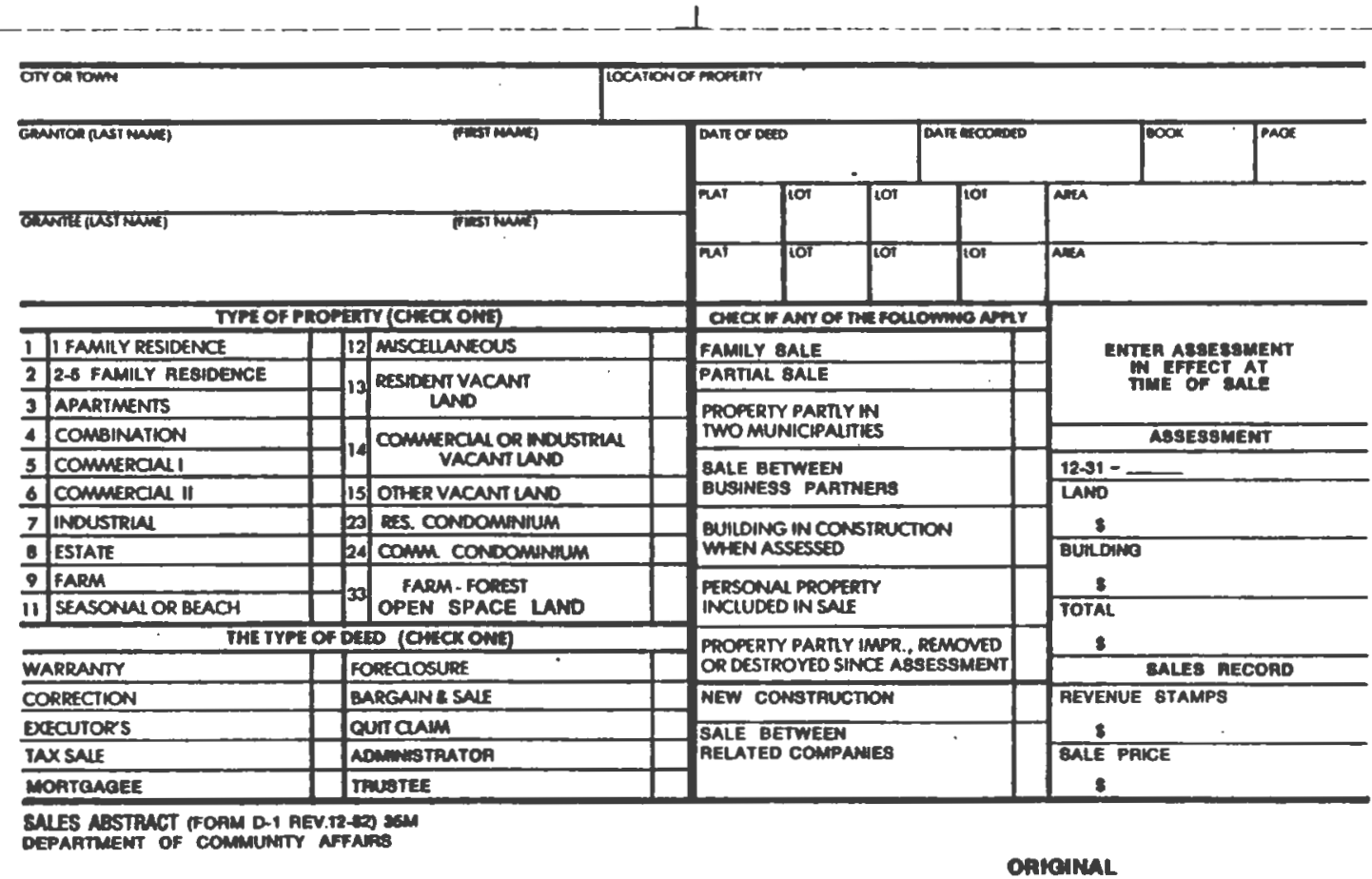

Sample of Sales Abstract to be completed by

Tax Assessor at the time of any real estate transfer. 


\section{APPENDIX B}

Correlation Tables

1. All Variables, 1963-1982

2. Selected Variables, 1963-1982

3. Selected Variables, 1963-1964

4. Selected Variables, 1965-1969

5. Selected Variables, 1970-1974

6. Selected Variables, 1975-1979

7. Selected Variables, 1980-1982 
VARIABLE LIST NUMBEF 1 LISTHISF CELETICN OF MISSING CATA

\begin{tabular}{|c|c|c|}
\hline & YE & $S I L \quad C E$ \\
\hline 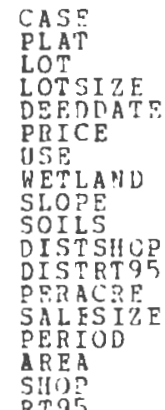 & $\begin{array}{r}70860.647 \\
14.259 \\
69.172 \\
36: 783 \\
70.716 \\
60031.353 \\
1.767 \\
: 543 \\
1.491 \\
2.108 \\
4.209 \\
1974.193 \\
2.000 \\
2.724 \\
2.716 \\
1.639\end{array}$ & $\begin{array}{r}5601.026 \\
3.342 \\
95.824 \\
34.492 \\
5.604 \\
75130.265 \\
4.805 \\
.908\end{array}$ \\
\hline
\end{tabular}

N OF LASES =

CORAELATION

- . is pilnted if a ccrrelation cannct be ccheuted.

\begin{tabular}{|c|c|c|c|c|c|c|c|c|c|c|c|c|c|}
\hline & CASE & PLAT & $\mathrm{LOT}$ & LOTSIZE & CEECCATE & PEICE & USE & HETLAND & $S L C P E$ & SCILS & DISTSHCE & DISTRTY 5 & EEOACir E \\
\hline $\begin{array}{l}\text { CASE } \\
\text { PLAT } \\
\text { LOT } \\
\text { LOTSIZE } \\
\text { DEEDDATE } \\
\text { PRICE } \\
\text { USE } \\
\text { WETLAND } \\
\text { SLOPE } \\
\text { SOITS } \\
\text { DISTSHOP } \\
\text { DISTRTOS } \\
\text { PERACRE }\end{array}$ & $\begin{array}{r}1.000 \\
.082 \\
: 205 \\
-.011 \\
1.000 \\
.377 \\
.372 \\
: 166 \\
-.078 \\
.074 \\
-0054 \\
.132 \\
.490\end{array}$ & $\begin{array}{r}-082 \\
1.000 \\
-.162 \\
-.025 \\
-081 \\
-.189 \\
-.103 \\
-036 \\
-0.043 \\
-.027 \\
.328 \\
-759 \\
-.269\end{array}$ & $\begin{array}{r}.205 \\
-.162 \\
1.000 \\
-.061 \\
: 203 \\
: 268 \\
-019 \\
-0019 \\
-059 \\
-065 \\
-0059 \\
-134 \\
.359\end{array}$ & $\begin{array}{r}-.011 \\
-.025 \\
-.061 \\
1.000 \\
-016 \\
.590 \\
-.182 \\
: 118 \\
: 110 \\
-156 \\
-.023 \\
-075 \\
-.162\end{array}$ & $\begin{array}{r}1.000 \\
: 081 \\
: 203 \\
: 016 \\
1.000 \\
.374 \\
.374 \\
: 166 \\
-.084 \\
.074 \\
-053.04 \\
.130 \\
.490\end{array}$ & $\begin{array}{r}-377 \\
-1188 \\
-268 \\
-590 \\
-374 \\
1.000 \\
-0001 \\
-030 \\
.072 \\
.094 \\
-204 \\
-109 \\
554\end{array}$ & $\begin{array}{r}.372 \\
-: 103 \\
-: 018 \\
-.182 \\
: 374 \\
-0001 \\
1.000 \\
: 069 \\
-060 \\
-133 \\
-.038 \\
-1112 \\
.283\end{array}$ & 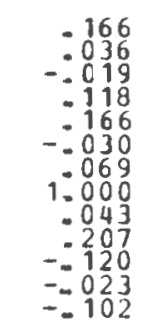 & $\begin{array}{l}-.078 \\
-.043 \\
-.058 \\
-110 \\
-0044 \\
-072 \\
-060 \\
-043 \\
1.000 \\
-172 \\
-194 \\
-100 \\
-046\end{array}$ & $\begin{array}{r}.074 \\
-.027 \\
-.066 \\
: 156 \\
: 074 \\
-094 \\
-.133 \\
: 207 \\
: 172 \\
1.000 \\
.043 \\
-040 \\
-.108\end{array}$ & $\begin{array}{r}-.054 \\
: 028 \\
-0.059 \\
-023 \\
-0053 \\
-204 \\
-038 \\
-0120 \\
-194 \\
: 043 \\
1.000 \\
-670 \\
-2772\end{array}$ & $\begin{array}{r}-132 \\
: 759 \\
-134 \\
-075 \\
-130 \\
-: 109 \\
-112 \\
-0023 \\
-: 100 \\
-040 \\
-670 \\
1.000 \\
-250\end{array}$ & $\begin{array}{r}.490 \\
-.268 \\
-358 \\
-.162 \\
.490 \\
.554 \\
.283 \\
-.104 \\
-.046 \\
-.108 \\
-.272 \\
-.258 \\
1.000\end{array}$ \\
\hline $\begin{array}{l}\text { SALESIZC } \\
\text { PEUIOD } \\
\text { AEEA } \\
\text { SHOD } \\
\text { BT }\end{array}$ & $\begin{array}{r}: 967 \\
: 197 \\
-019 \\
.061\end{array}$ & $\begin{array}{l}: 063 \\
: 648 \\
-262 \\
.745\end{array}$ & $\begin{array}{r}.213 \\
-152 \\
-150 \\
-: 070\end{array}$ & $\begin{array}{r}\because 058 \\
: 111 \\
-041 \\
.057\end{array}$ & $\begin{array}{r}: 968 \\
: 196 \\
-018 \\
: 057\end{array}$ & $\begin{array}{r}: 337 \\
-: 085 \\
: 2332 \\
-: 118\end{array}$ & $\begin{array}{r}\because 434 \\
-\because 102 \\
-=036 \\
-.146\end{array}$ & $\begin{array}{r}: 156 \\
-144 \\
: 845 \\
-044\end{array}$ & $\begin{array}{l}\therefore 080 \\
\because-087 \\
-124 \\
-096\end{array}$ & $\begin{array}{l}=060 \\
.119 \\
0074 \\
.011\end{array}$ & $\begin{array}{r}-.052 \\
.306 \\
.864 \\
.665\end{array}$ & $\begin{array}{r}-084 \\
-084 \\
.687 \\
-573 \\
.946\end{array}$ & - \\
\hline
\end{tabular}




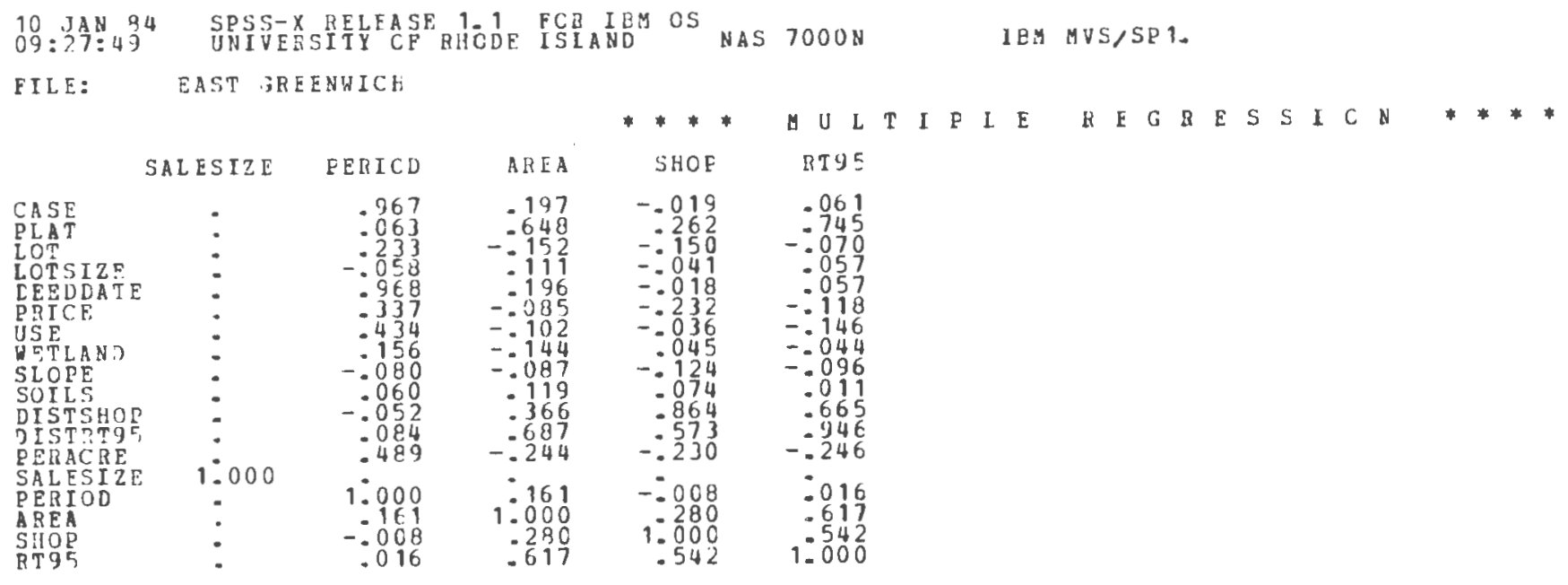

1. All Variables, 1963-1982 (Continued) 
VAKIABLE LIST NUIBER 1 LISTHISE CELETICN OF MISSING CATA

$$
\text { MEAN STD DEVI LABEL }
$$

\begin{tabular}{|c|c|c|}
\hline 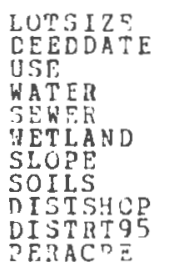 & $\begin{array}{r}36.783 \\
73.716 \\
13.767 \\
.457 \\
.069 \\
-543 \\
.034 \\
1.491 \\
2.108 \\
4.209 \\
1974.193\end{array}$ & $\begin{array}{r}34.492 \\
5.604 \\
4.805 \\
: 751 \\
: 316 \\
: 908 \\
: 183 \\
1.115 \\
1.131 \\
1.720 \\
2273.818\end{array}$ \\
\hline$\| O E$ CASE & 116 & \\
\hline
\end{tabular}

$\| O F$ CASES $=116$

CUIRELATION:

$$
\text { LOTSIZE LEELEATE }
$$
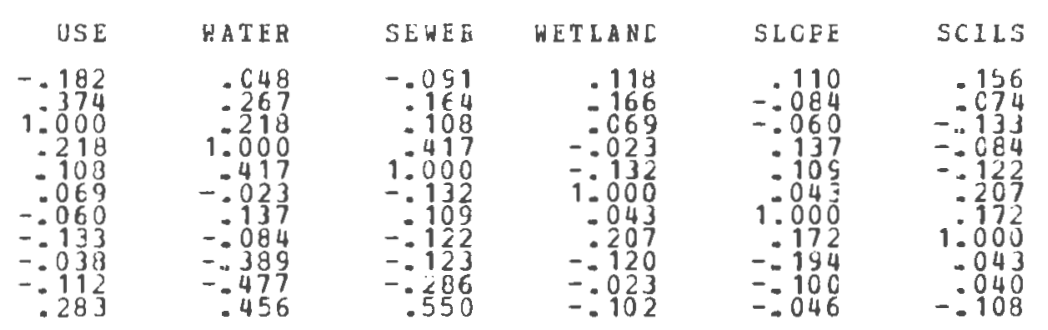

CISTSHCP DISTET 95

EELACEE

LOTSIZE
DEENDATE
USE
WATER
SE EER
GETLAND
SLODE
SOILS
DISTSHUD
DISTRT
DEAACRE

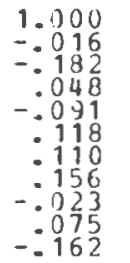

-016
$1: 000$
$: 374$
$: 267$
$: 164$
$: 166$
-0084
$: 074$
-0.053
$: 130$
.490

28

2. Selected Variables, 1963-1982 
VARIABLE LIST NUMBEF 1 LISTHISF DELETICN CF MISSING CATA

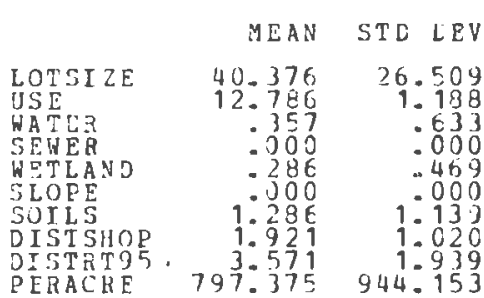

$$
\text { IABEL }
$$

JF CASFS =

CORRELATION:

'. is printad ip a clrrflaticn cannct af ccmeuted.

\begin{tabular}{|c|c|c|c|c|c|c|c|c|c|c|}
\hline & LOTSIZE & IJSF & WATER & SEWER & WETLAAD & SLOEE & SCIIS & DISTSHCE & DISTRTg5 & EEBACEE \\
\hline $\begin{array}{l}\text { LOTSIZE } \\
\text { OSEE } \\
\text { WATEM }\end{array}$ & $\begin{array}{l}1.009 \\
-: 319 \\
-.113\end{array}$ & $\begin{array}{r}-319 \\
1: 900 \\
.314\end{array}$ & $\begin{array}{r}-.113 \\
-314 \\
1.0000\end{array}$ & : & $\begin{array}{r}-504 \\
-.296 \\
-407\end{array}$ & $:$ & $\begin{array}{r}-.181 \\
: \begin{array}{r}33 \\
: 16 \varepsilon\end{array}\end{array}$ & $\begin{array}{r}-.426 \\
-398 \\
-023\end{array}$ & $\begin{array}{r}-.149 \\
-0024 \\
-.611\end{array}$ & $\begin{array}{r}-.359 \\
-.233 \\
-773\end{array}$ \\
\hline $\begin{array}{l}\text { SENEA } \\
\text { WETLAND }\end{array}$ & $: 504$ & $-: 296$ & $: 407$ & 1.000 & 1.000 & & $-\therefore 021$ & $-: 110$ & -473 & $: 340$ \\
\hline
\end{tabular}

3. Selected Variables, 1963-1964 
VARLABLE LIST NUMBER 1 LISTWISE DELLION OF MISSING LATA

$$
\text { MEAN STD DEVI LABEL }
$$

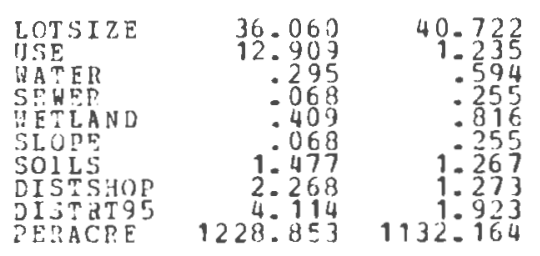

N OF CASES =

CORRFLATICN:

\begin{tabular}{|c|c|c|c|c|c|c|c|c|c|c|}
\hline & LGTSIZE & USE & HATEB & SEWER & WETLAND & SLCEE & $S C I I S$ & CISTSHCP & DISTBI95 & EE $\triangle A C C E E$ \\
\hline $\begin{array}{l}\text { LOTSIZE } \\
\text { WSE } \\
\text { HATER } \\
\text { SEWER } \\
\text { WETLAND } \\
\text { SIOPE } \\
\text { SOTLS } \\
\text { DISTSHCE } \\
\text { DISTPTYS } \\
\text { PEIRACRE }\end{array}$ & $\begin{array}{r}1.000 \\
-.465 \\
-: 089 \\
-.108 \\
: 084 \\
-.032 \\
-154 \\
.067 \\
-0044 \\
-.023\end{array}$ & $\begin{array}{r}-.405 \\
1.000 \\
.069 \\
.094 \\
-0008 \\
.094 \\
.043 \\
.105 \\
-.006 \\
-.358\end{array}$ & $\begin{array}{r}-.089 \\
.069 \\
1.000 \\
-0.032 \\
-063 \\
-: 171 \\
-: 285 \\
-: 320 \\
-: 553 \\
.245\end{array}$ & $\begin{array}{r}-.108 \\
.094 \\
-632 \\
1.000 \\
-.137 \\
-295 \\
-.103 \\
-.215 \\
-.386 \\
.078\end{array}$ & $\begin{array}{r}-024 \\
-: 008 \\
-: 063 \\
-1.137 \\
1.000 \\
-006 \\
-207 \\
-: 258 \\
-: 147 \\
-.178\end{array}$ & $\begin{array}{r}-.032 \\
-094 \\
.171 \\
-285 \\
.086 \\
1.000 \\
-257 \\
-.287 \\
-163 \\
-056\end{array}$ & $\begin{array}{r}-154 \\
-043 \\
-.285 \\
-.103 \\
-257 \\
-257 \\
1.000 \\
-120 \\
-.170 \\
-.235\end{array}$ & $\begin{array}{r}.067 \\
: 105 \\
-: 320 \\
-: 215 \\
-\because 258 \\
-: 287 \\
1.125 \\
1.000 \\
-628 \\
-.453\end{array}$ & $\begin{array}{r}.084 \\
.006 \\
-: 558 \\
-: 386 \\
-: 147 \\
-: 163 \\
: 170 \\
: 628 \\
1.000 \\
-.283\end{array}$ & 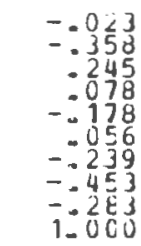 \\
\hline
\end{tabular}


VARIABLE LIST NUMBER 1 LISThISF DEIETICN OF MISSING CAIA

$$
\text { MEAN STD DEVI LABEL }
$$

\begin{tabular}{|c|c|c|}
\hline 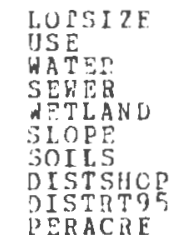 & $\begin{array}{r}39.547 \\
12.231 \\
.385 \\
: 000 \\
-652 \\
.038 \\
1.395 \\
1.981 \\
4.588 \\
2005.393\end{array}$ & $\begin{array}{r}34.156 \\
2.717 \\
.752 \\
: 000 \\
: 928 \\
: 196 \\
: 933 \\
.984 \\
1541.755\end{array}$ \\
\hline
\end{tabular}

NCF CASFS $=26$

CORBELATION:

1. is printad if a ccrrelaticn canct be comeuted.

\begin{tabular}{|c|c|c|c|c|c|c|c|c|c|c|}
\hline & LOTSIZ̈E & USF & WATER & SEKER & WET L A K D & SLCEE & SCILS & DISISHCP & DISIRI95 & EEGACEE \\
\hline $\begin{array}{l}\text { LOTSIZE } \\
\text { MSETER }\end{array}$ & $\begin{array}{r}1.000 \\
-.177 \\
.223\end{array}$ & $\begin{array}{l}\overline{1}: 177 \\
1.000 \\
-.202\end{array}$ & $\begin{array}{r}-223 \\
-: 202 \\
1.000\end{array}$ & $:$ & $\begin{array}{r}270 \\
-251 \\
-2110\end{array}$ & $\begin{array}{r}.560 \\
-: 242 \\
.438\end{array}$ & $\begin{array}{r}-29 \mathrm{E} \\
-: 184 \\
-.04 \mathrm{t}\end{array}$ & $\begin{array}{r}-.011 \\
-.162 \\
-.0427\end{array}$ & $\begin{array}{l}=212 \\
=-004 \\
=.436\end{array}$ & $\begin{array}{r}-.0305 \\
.034 \\
.250\end{array}$ \\
\hline $\begin{array}{l}\text { SEHER } \\
\text { WFTLAND } \\
\text { SLOEE } \\
\text { SOTLS } \\
\text { DISTSHOP } \\
\text { DISTRTOS } \\
\text { PFPACRE }\end{array}$ & $\begin{array}{r}: 270 \\
: 560 \\
-296 \\
-.011 \\
-212 \\
-.305\end{array}$ & $\begin{array}{r}-251 \\
-: 242 \\
-: 194 \\
: 162 \\
-0004 \\
.034\end{array}$ & $\begin{array}{r}-\because 110 \\
-438 \\
-.046 \\
-.427 \\
-.436 \\
: 250\end{array}$ & $:$ & $\begin{array}{r}1: 000 \\
: 0 \notin 8 \\
: 179 \\
: 129 \\
: 171 \\
-: 352\end{array}$ & $\begin{array}{r}.068 \\
1.000 \\
-: 128 \\
: .203 \\
-0.038 \\
-.092\end{array}$ & $\begin{array}{r}: 179 \\
: 128 \\
1: 000 \\
: 3115 \\
: 153 \\
-: 138\end{array}$ & $\begin{array}{r}-129 \\
-: 203 \\
-\because 315 \\
1.0000 \\
-8078 \\
-.0480\end{array}$ & $\begin{array}{r}: 171 \\
-038 \\
-0153 \\
-878 \\
-800 \\
-.540\end{array}$ & $\begin{array}{l}-.352 \\
=.092 \\
=.138 \\
=.480 \\
-5.540 \\
1.000\end{array}$ \\
\hline
\end{tabular}


VARIABLE LIST NUMBE 1 LISTHISE DELETICN CE MISSING CATA

MEAN STD DEVI LABEL

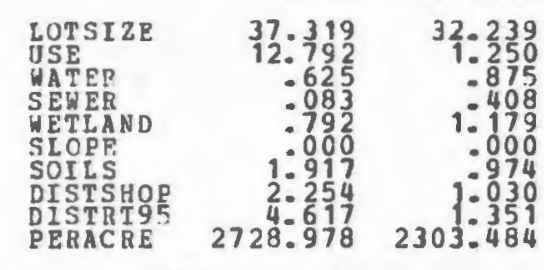

2.239
1.250

-875
1.408
1.000

1.030

N OF CASES = 24

COBRELATION :

- - is printed if a correlation cannct be conputec.

\begin{tabular}{|c|c|c|c|c|c|c|c|c|}
\hline & LOTSIZE & USE & WATEB & SEUER & WETLABD & SLOPE & ScILs & DISTSHCP \\
\hline $\begin{array}{l}\text { LOTSIZE } \\
\text { USEE } \\
\text { WATER } \\
\text { SEWER } \\
\text { HETLAND }\end{array}$ & $\begin{array}{r}1.000 \\
-004 \\
-368 \\
-.030 \\
.054\end{array}$ & $\begin{array}{r}.004 \\
1.000 \\
: 293 \\
: 206 \\
.294\end{array}$ & $\begin{array}{r}.368 \\
: 283 \\
1.000 \\
-335 \\
-.037\end{array}$ & $\begin{array}{r}-.030 \\
-206 \\
-335 \\
1.000 \\
-.143\end{array}$ & $\begin{array}{r}.054 \\
: 294 \\
-: 037 \\
: 1.43 \\
1.000\end{array}$ & $:$ & $\begin{array}{r}1144 \\
: 021 \\
-115 \\
-200 \\
-136\end{array}$ & $\begin{array}{l}= \\
= \\
=\end{array}$ \\
\hline $\begin{array}{l}\text { SLOPE } \\
\text { SOILS } \\
\text { DISTSHOP } \\
\text { DISTRT } 95 \\
\text { PERACBE }\end{array}$ & $\begin{array}{r}: 144 \\
\because 209 \\
: 107 \\
-: 153\end{array}$ & $\begin{array}{r}: 021 \\
: 001 \\
-: 327 \\
: 157\end{array}$ & $\begin{array}{r}: 115 \\
-: 540 \\
-: 425 \\
-469\end{array}$ & $\begin{array}{l}=-200 \\
=156 \\
=350 \\
-572\end{array}$ & $\begin{array}{r}: 136 \\
:-169 \\
: 028 \\
-: 198\end{array}$ & $\begin{array}{l}1.000 \\
\vdots\end{array}$ & $\begin{array}{r}1=000 \\
-048 \\
=200 \\
-146\end{array}$ & $\therefore$ \\
\hline
\end{tabular}


VAIABLE LIST NUMBEB 1 LISTUISE CELETION OF MISSING CATA

HEAN STD DEVI LABEL

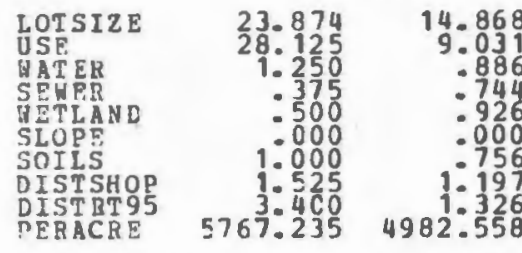

N OF CASES =

8

CORBELATION:

- - is pbinted tF a corbelation cannot be comeuted.

\begin{tabular}{|c|c|c|c|c|c|c|c|c|c|c|}
\hline & LCTSIZE & USE & MATEB & SELER & WETLAED & SLOEE & SCILS & CISTSHCP & DISTEI95 & PELACEE \\
\hline $\begin{array}{l}\text { LOTSIZE } \\
\text { JSE } \\
\text { YATER } \\
\text { SEGER } \\
\text { WETLANE }\end{array}$ & $\begin{array}{l}1.000 \\
=.447 \\
=.416 \\
-.224 \\
-.485\end{array}$ & $\begin{array}{r}-.447 \\
1.000 \\
-.165 \\
-: 497 \\
.333\end{array}$ & $\begin{array}{r}-.416 \\
=165 \\
1.000 \\
-487 \\
-174\end{array}$ & $\begin{array}{r}-.224 \\
-.497 \\
.487 \\
1.000 \\
-.311\end{array}$ & $\begin{array}{r}-.485 \\
-333 \\
-1374 \\
-1: 311 \\
1.000\end{array}$ & $:$ & $\begin{array}{r}-399 \\
-: 415 \\
=-213 \\
-254 \\
-408\end{array}$ & $\begin{array}{r}-217 \\
-277 \\
-666 \\
-068 \\
-064\end{array}$ & $\begin{array}{r}-540 \\
-131 \\
-.839 \\
-.492 \\
-.093\end{array}$ & $\begin{array}{r}-.425 \\
-: 30 \\
-432 \\
-823 \\
-.194\end{array}$ \\
\hline
\end{tabular}


Binkley, Clark S., et al. Interceptor Sewers and Urban Sprawl. Lexington, Mass: D.C. Heath and Co., 1975.

Brown, James H.; Phillips, Robyn S.; Roberts, Neal A. "Land Markets at the Urban Fringe." Journal of the American Planning Association 47, 2: $131-144$.

Cady, John H. and Menhincih, Howard K. Planning and Zoning in Rhode Island. Providence: Rhode Island State Planning Board, Special Report No. 11, 1937.

Clawson, Marion. "Urban Sprawl and Speculation in Suburban Land." Land Economics 28 (May 1962):99-111.

Cronin, John C. "The Behavior of Rural Landowners in Response to Local Economic Development." Master's Thesis, University of Rhode Island, 1981.

East Greenwich Planning Board. East Greenwich Land Use Analysis (November 1961).

early 1960's?') - Zoning Study (Undated,

East Greenwich, Town of. A Comprehensive Community Plan. Adopted November $19 \overline{82}$. - A Comprehensive Community Plan. Adopted 1972 . - A Comprehensive Community Plan. Adopted 1966 - Plat Maps (Amended up to and including 1965 . - Plat Maps (Amended up to and including 1982 . - Subdivision Regulations 11963 and 1982). - Tax Book (1940,1970 and 1983). - Zoning Ordinance (1963 and 1982). 
Getzels, Judith and Thurow, Charles, eds. Rural and Small Town Planning. Chicago: American Planning Association, 1979 .

Hagman, Donald G. Urban Planning and Land Development Control Law. St. Paul: West Publishing Co., 1975.

Healy, Robert G., and Short, James L. The Market for Rural Land. Washington, D.C.: The Conservation Foundation, $\overline{1981}$.

Healy, Robert G., and Short, James L. "Rural Land: Market Trends and Planning Implications." Journal of the American Planning Association 45, 3:305-317.

Hershey, Stuart S., and Garmise, Carolyn. "Streamlining Local Regulations: A Handbook for Reducing Housing and Development Costs." Washington, D.C.: International City Management Association, Management Information Service. Report No. 11, May 1983.

Hughes, Sarah; Jablonski, Cathleen; Joly, Richard; Landis, John; and Tassinari, Robert. "Housing Price Models for Rhode Island." 1983. (Unpublished.)

Kaiser, E.J.; Massie, R.W.; Weiss, S.F.; and Smith, J.E. "Predicting the Behavior of Predevelopment Landowners on the Urban Fringe." Journal of American Economics 34:328-333

Lefaver, Scott. "A New Framework for Rural Planning." Urban Land $32,4: 7-13$.

Lindeman, Bruce. "Anatomy of Land Speculation." Journal of the American Institute of Planners 42, $2: 1 \overline{42-152 .}$

Loranger, John E. "The Property Tax and Residential Land Use in East Greenwich, Rhode Island." Master's Thesis, University of Rhode Island, 1974.

Mahayni, Riad G., and Reich, Marguerite P. Fiscal and Environmental Impacts of Subdivision Regulations in Rhode Island. Kingston: University of Rhode Island Agricultural Experiment Station (Bulletin 430, December 1979).

Netter, Edith, and Vranicar, John. Linking Plans and Regulations. Washington, D.C.: American Planning Association, Planners Advisory Service (Report No. 363, $1981)$. 
Nie, N.H.; Hull, C.H.; Jenkins, J.G.; Steinbrenner, K.: and Bent, D.H. Statistical Package for the Social Sciences. New York: McGraw-Hill Book Co., 1975.

Rhode Island Department of Community Affairs. Tax Equalization Division. Real Estate Sales Abstracts, 19631982 .

- "Available

Industrial Sites: East Greenwich." 1981.

, Planning

and Development Division. "Rhode Island State

Enabling Acts." Planning Paper No. 7, 1978.

Rhode Island Development Council. Planning Division. Land Use Controls in Rhode Island (Publication No. 6, March 1963).

Rhode Island Department of Economic Development. Rhode Island Basic Economic Statistics, 1982-1983 (1982).

Rhode Island Department of Economic Development. Rhode Island City and Town Monographs: East Greenwich

(october 1976).

Tabors, Richard D.; Shapiro, Michael H.: and Rogers, Peter P. Land Use and the Pipe: Planning for Sewerage.

Lexington, Mass: D.C. Heath and Co., 1976.

U.S. Department of Agriculture. Soil Conservation Service. Soil Survey of Rhode Island. Washington, D.C.: Government Printing office, 1981.

Interim Soil Survey Report for East Greenwich, Rhode Island (1974).

U.S. Department of Commerce. Bureau of the Census. United States Census of Population: 1960, 1970 and $19 \overline{980}$. General Populaiton Characteristics and Social and Economic Characteristics, Rhode Is 1 and.

States Census of Population and Housing: 1960, 1970 and 1980. General Population and Housing Characteristics, Rhode Island.

U.S. Department of the Interior. Geological Survey. Wickford, Slocum, East Greenwich and Crompton Quadrangles. 7.5 Minute Series (Topographic). 1975 . 
Yearwood, Richard M. Subdivision Regulations. New York: Praeger Publications, 1971. 